\title{
Evolution of root form endosseous dental implant- Transformation from bone anchored to ligament anchored implants and its neurological aspects
}

\author{
Siddhartha Das ${ }^{1,2} V_{i v e k}$ Soni ${ }^{1}$, and Jayesh R Bellare ${ }^{2,3 *}$ \\ ${ }^{1}$ Department of Bioscience and Bioengineering, Indian Institute of Technology Bombay, Mumbai 400 076, India \\ ${ }^{2}$ Department of Chemical Engineering, Indian Institute of Technology Bombay, Mumbai 400 076, India \\ ${ }^{3}$ Wadhwani Research Center for Bioengineering (WRCB), Indian Institute of Technology Bombay, Mumbai 400 076, India
}

\begin{abstract}
This review paper investigates the possible transformation of endosseous dental implant, primarily from the current osseointegrated to the future ligament anchored implant within which a new class of implants with enhanced feature of "neuro-ligament integration" may appear. Endosseous dental implants used presently to replace missing teeth get fused with bone but they do not have any periodontal ligament interface between the alveolar socket and the surface of the implant, which natural teeth do. Hence, they lack any proprioceptive sensation, which is important for discrimination, directional and masticatory sensation. Attempts have been made to regenerate periodontium around the implant in $90 \mathrm{~s}$, which was not completely successful. Thereafter, there has been limited research. However, recent advances in tissue engineering and biomaterials gave renewed hope of establishing sensory dental implants. In this review, various methods of regeneration of periodontium onto the surface of titanium implants have been discussed along with the possible types of neurological assessment and neuroimaging that could be carried out for validation of its afferent feedback. The review starts by giving background information of major stages and terminologies in the field of oral implants, its response to host tissue in bone, various surface modification of dental implants, stem cells that are used for periodontal regeneration, different approaches for regeneration of periodontium, concept of proprioception in periodontium, osseoperception of dental implants and concludes with neurophysiology of oro-dentofacial region in brain including its detection and measurements methods.
\end{abstract}

\section{Glossary of important terms}

Proprioception: Proprioception is a type of sensory function of periodontium. Proprioception, also called kinesthesia, involves awareness of the spatial and mechanical status of the musculoskeletal framework.

Osseoperception: The ability to identify kinesthetic sensation without the input from periodontal mechanoreceptors. This sensation is generated from the temporomandibular joint, masticatory muscle, mucosa, and periosteum, and provides sensory and motor information related to mandibular movements and occlusion.

Stereognosis: Stereognosis (haptic perception or tactile gnosis) is the ability to identify and discriminate various forms. It depends upon memory and intact somatic sensory system. Both, central analysis and peripheral receptors are involved.

\section{Introduction}

Dental caries is one of the commonest disease known to mankind [1]. Dental caries and periodontal pathosis results in destruction of tooth structure and attachment apparatus which ultimately leads to tooth loss. The edentulous space arising out of tooth loss leads to other complications like midline shifting of facial profile [2], supra-eruption of opposing tooth [3], masticatory imbalance [4], rapid bone loss [5], disruption of dynamic equilibrium of the masticatory apparatus [6], defective speech [7] etc. Hence, time immemorial people used various substitute to replace the lost tooth in edentulous region. Probably, the first artificial implant were pieces of shells that were used as implants for mandibular teeth in Mayan population roughly around $600 \mathrm{AD}$ [8].

In 1952, Per-Ingvar Brånemark, a Swedish orthopedic surgeon, while conducting experiments on intravascular rheology implanted titanium chamber on rabbit femur. However, after the completion of the experiment these titanium chambers could not be retrieved as surrounding bone fused with them permanently. He named this bone anchored phenomena as "osseointegration" [9]. He further stated that the surrounding bone approximates the implant surface very closely without any intervening connective tissue. "Osseointegration implies a firm, direct and lasting connection between the vital bone and screwshaped titanium implants of defined finish and geometry-fixtures. Thus, there is no interposed tissue between fixture and bone. Osseointegration can only be achieved and maintained by a gentle surgical installation

Correspondence to: Jayesh Bellare, Professor, Department of Chemical Engineering, Indian Institute of Technology Bombay, Tel: Phone: +91-02225764204, Fax: +91-022-25726895; Email- jb@iitb.ac.in

Key words: endosseous titanium dental implant, neuroligament integration, osseointegration, periodontal regeneration, proprioception

Received: March 09, 2017; Accepted: March 26, 2017; Published: March 29, 2017 
technique, a long healing time and a proper stress distribution when in function" [10]. For proper osseointegration to occur, the implant should not be loaded and left out of function during the healing period.

In 1986, Dr.Charles Wiess came up with another concept of implant biointegration which he termed as "fibro-osseous integration"[11]. According to him, when implant is subjected to micromotion, a type of connective tissue fibres viz. collagen fibres get interposed between the trabecular bone, weaving around the implant surface and then reinvesting into the trabecular bone on the other side. Early loading of such implants results in generation of bioelectricity (piezoelectric effect) due to polarity in the outer and inner surface of the investing collagen fibres resulting in differentiation of pluripotent cells present in the peri-implant area with predictable sequalae. He also suggested that dental implants integrated through fibro-osseous integration is superior to the osseointegrated implants. The fibro-osseous integrated implants showed initial success but in long term they failed as the collagen fibres were oriented parallely. These collagen fibres cannot mimic the function of Sharpey's fibres that were inserted in perpendicular fashion in the root cementum [12-14]. Schroeder et al. gave the term "functional ankylosis" to define osseointegration after he minutely examined the histological sections [15]. He opined that primary stability (initial fixation) is mandatory for functional ankylosis of the implant. This is achieved by the firm and frictional/contact relationship between the cortical bone and the implant surface.

De Putter stated that implant anchorage could be of two typesmechanical and bioactive anchorage [16]. Mechanical anchorage is seen in metallic implants such as titanium and is generated by interfacial tension of surface undercuts in the form of vents, slots, screws etc. The anchorage is purely physical and there is a direct contact between the metal surface and bone. Bioactive retention is achieved when the implant surface is coated with a bioactive material like hydroxyapatite which induces osteogenesis resulting in physicochemical bond between implant surface and bone similar to ankylosis of natural tooth $[13,14,16]$. Further, peri-implant bone healing may elicits two types of mechanism - contact and distance osteogenesis. In contact osteogenesis bone starts forming from the implant surface while in distance osteogenesis, bone starts getting deposited on the old bone and move towards the implant surface in an appositional manner [13,17-19]. Although dental implants provides permanent solution to missing teeth, they have got their own limitations. The treatment is considered successful if the implant permanently fuses with the bone. This "ankylosed" process does not mimic the natural healthy tooth apparatus which contains the sensitive periodontium between the root of tooth and wall of the alveolar bone socket. Hence, dental implant ankylosed to alveolar bone do not display the functions of healthy periodontium as those found in natural tooth like defence and proprioception including sensation of mastication, occlusion, directional and discriminative abilities. Research is being conducted to regenerate functional periodontium ${ }^{1}$ around dental implant to counter these drawbacks and this is a focus of this review paper.

\section{Host response to implants}

Dental implants are broadly classified into two types - endosteal (root form) implants and subperiosteal implants. Endosteal implants are placed in the jaw bone while subperiosteal implants are placed above it. We will focus on root form endosteal implants as these are the anatomic substitutes of dental root(s). A root form dental implant is placed in region of missing maxillary or mandibular teeth surgically, taking into consideration the systemic and oral health of the patients. After the implant has been placed in the biological system (alveolar bone), water molecules are the first molecules to reach the surface of the implant [20]. Surface properties of the implant determines how water molecules behaves with the implant surface. The surface water shell determines the fate of biomolecules and proteins that adsorb later onto the implant surface. It has been suggested that biomolecules also have hydration water shells which interacts with surface water shells and drives the physicochemical process at the interface [20] (Figure 1).

Later as stated by Branemark in 1985, the microgap between the implanted surface and the wall of the drilled hole is filled by blood clot. Primary stability of the implant fixture leads to uneventful healing which was termed as "intramembranous bone formation" by Schenk and Hunziker [21] and "de novo bone formation" by Davies [17]. In intramembranous bone formation, blood clot surrounds the implant surface, followed by angiogenesis, osteoprogenitor cell migration, woven bone formation and compaction (deposition of parallel fibres and lamellar bone) and secondary remodelling [22]. There is a correlation between microdamage induced during the surgical placement of implant and bone remodelling. The damaged bone triggers cascade of healing response [23]. The interface between the implant surface and the inner wall of the osseous drilled hole follows the sequence of wound healing as depicted in the Figure 2.

Briefly, the local tissue response at the implant site depends on body's response to surgical trauma induced by placement of root form endosseous dental implant fixture. Prognosis is better with optimal tissue response when there is minimal generation of heat $\left(<47^{\circ} \mathrm{C}\right.$ for $1 \mathrm{~min}$ or less) during osteotomy procedures coupled with surgical precision. A vascular clot gets formed at the inflamed surgical site. This attracts macrophages/large phagocytes and undifferentiated mesenchymal cells from surrounding periosteum. Osteoblast, the polarized cells are known to be the chief bone matrix synthesizing cells. When they are completely covered by the matrix they are called osteocytes. Appositional bone growth occurs onto the implant surface by contact osteogenesis by these osteoblast cells. It has been suggested that with the initial placement of the implant a thin layer of bone $(0.5$ $\mathrm{mm}$ ) becomes necrotic (even with optimal surgical technique) which will be replaced by woven bone with vascularization resulting in initial bone contact [24]. This woven bone matrix will be removed by hematopoietic derived osteoclastic cells by a process called remodelling. A mature haversian bone system is laid down by osteoblastic cells to form lamellar bone. This process is influenced by micromotion of the interface, local and systemic release of matrix regulating growth factors, local vascular supply etc. Later the space between the implant and bone is healed by a process called "creeping substitution" resulting in secondary stability of the implant [25]. Some authors categorized the above events as SIGMA phase consisting of Activation (A), Resorption (R), Quiescence or reversal (Q) and Formation (F) stages [12]. The final maturation and adaptation phase continues for years. Here the bone callus is resorbed and stronger bone structure develops in the regions of higher strain (Wolf's law) to resist mechanical stress and strain [26]. The effect of many inflammatory mediators, eicosanoids, interleukins, chemokines on bone formation and osteoblast behaviour strongly implicates the post surgical inflammatory process in determination of bone formation.

\section{Surface modification of titanium dental implants}

Currently surface modification of the commercial endosseous dental implants is done to improve bone integration. No such instances have been reported where the implant surface or design was modified purely for ligament tissue proliferation and anchoring (Table 1). 


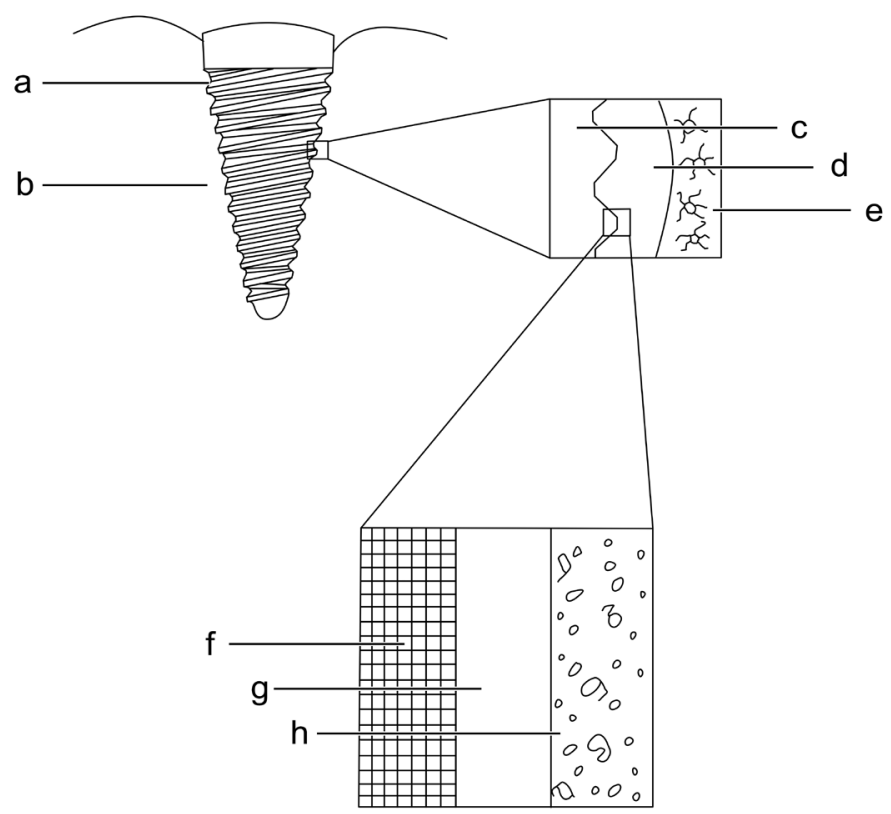

Figure 1. Biological response of endosseous dental implant: a- Titanium implant, b- Alveolar bone, c- Surface of titanium implant, d- Biofluid, e- Osteocytes and bone, f- Titanium,gTitanium oxide, h- Biofluid with proteins and ions.

Table 1. Some work involving surface modification of titanium dental implant are listed in the following table.

\begin{tabular}{|c|c|c|c|c|c|}
\hline Author and year & $\operatorname{Aim}$ & Surface modification & Process applied & Study & Conclusion \\
\hline $\begin{array}{l}\text { Bowers KT et al. } 1992 \\
{[27]}\end{array}$ & $\begin{array}{c}\text { Responses of osteoblast-like } \\
\text { cells were studied on titanium } \\
\text { surfaces }\end{array}$ & Roughness increased & Sandblast & In vitro & $\begin{array}{l}\text { Increased osteoblast attachment were found in } \\
\text { modified implant }\end{array}$ \\
\hline Sul YT et al. 2002 [28] & $\begin{array}{c}\text { Investigation of chemical } \\
\text { properties of titanium surface } \\
\text { for osseointegration }\end{array}$ & $\begin{array}{l}\text { Altered surface chemical } \\
\text { composition. }\end{array}$ & $\begin{array}{l}\text { Electrochemical deposition } \\
\text { of calcium ions }\end{array}$ & In vivo & Fast and strong osseointegration \\
\hline $\begin{array}{l}\text { Jimbo R et al. } 2011 \\
{[29]}\end{array}$ & $\begin{array}{l}\text { Investigation of in vivo bone } \\
\text { apposition during the early } \\
\text { stages of osseointegration }\end{array}$ & Increased hydrophilicity & $\begin{array}{l}\text { Anodized porous titanium } \\
\text { implants were modified } \\
\text { with } 0.175 \mathrm{wt} \% \text { ammonium } \\
\text { hydrogen fluoride solution } \\
\quad(\mathrm{NH}(4) \mathrm{F}-\mathrm{HF}(2))\end{array}$ & In vivo & Enhanced cellular response \\
\hline Lee JK et al. 2013 [30] & $\begin{array}{l}\text { Investigation of orthotropic } \\
\text { bone formation and } \\
\text { remodeling of dental implant } \\
\text { surfaces with and without } \\
\text { recombinant human bone } \\
\text { morphogenetic protein } 2\end{array}$ & $\begin{array}{l}\text { Bioinductive surface for } \\
\text { osseointegration }\end{array}$ & $\begin{array}{l}\text { Coated with bone } \\
\text { morphogenic protein- } 2\end{array}$ & In vivo & $\begin{array}{l}\text { Absorbed BMP-2 dose varied with implant surface } \\
\text { characteristics, } \\
\text { influencing local bone formation and remodeling. }\end{array}$ \\
\hline $\begin{array}{l}\text { Alghamdi HS et al. } \\
2013 \text { [31] }\end{array}$ & $\begin{array}{l}\text { Study of osseointegration of } \\
\text { Calcium Phosphate }(\mathrm{CaP}) \\
\text { coating in titanium implant in } \\
\text { healthy and osteoporotic rats }\end{array}$ & $\begin{array}{l}\text { Altered surface chemical } \\
\text { composition }\end{array}$ & $\begin{array}{l}\text { Radio-frequent magnetron- } \\
\text { sputtered calcium phosphate } \\
\quad(\mathrm{CaP}) \text { coating }\end{array}$ & In vivo & $\begin{array}{l}\text { Thin CaP coating effectively improves } \\
\text { osseointegration in both } \\
\text { healthy and osteoporotic conditions. }\end{array}$ \\
\hline $\begin{array}{l}\text { Wennerberg A et al. } \\
1996[32]\end{array}$ & $\begin{array}{c}\text { Comparative study between } \\
\text { different size of } \mathrm{Al}_{2} \mathrm{O}_{3} \text { on the } \\
\text { titanium implant }\end{array}$ & $\begin{array}{l}\text { Roughness } \\
\text { increased }\end{array}$ & Blast with $\mathrm{Al}_{2} \mathrm{O}_{3}$ & In vivo & $\begin{array}{c}\text { More bone-to implant contact and higher resistance to } \\
\text { reverse torque } \\
\text { in coarser implant }\end{array}$ \\
\hline $\begin{array}{l}\text { Perry R. Klokkevold et } \\
\text { al. } 1997 \text { [33] }\end{array}$ & $\begin{array}{l}\text { Acid etched implant surfaces } \\
\text { are thought to enhance } \\
\text { osseointegration }\end{array}$ & $\begin{array}{l}\text { Roughness } \\
\text { increased }\end{array}$ & Acid etching $\left(\mathrm{HCl} / \mathrm{H}_{2} \mathrm{SO}_{4}\right)$ & In vivo & $\begin{array}{l}\text { Resistance to reverse torque rotation implies enhanced } \\
\text { osseointegration }\end{array}$ \\
\hline $\begin{array}{c}\text { Mustafa K et al. } 2000 \\
{[34]}\end{array}$ & $\begin{array}{l}\text { Responses of cells derived } \\
\text { from mandible were studied }\end{array}$ & $\begin{array}{l}\text { Roughness } \\
\text { increased }\end{array}$ & Blast $\left(\mathrm{TiO}_{2}\right)$ & In vitro & Rough surface showed increased cellular attachment \\
\hline
\end{tabular}

\section{Stem cells used for periodontal regenerations}

Regeneration of periodontal like tissue by using stem cells from various origin has been reported by numerous authors [35-37]. Hence, it becomes imperative to discuss stem cells in relation to periodontal regeneration. Briefly, stem cells are classified as embryonic (pluripotent) and adult (multipotent) stem cells based on their origin and differentiation potential and are isolated from inner cell layer of blastocyst and tissues that continuously replenish themselves (intestinal epithelium, blood, skin etc.) respectively [38]. One of the most common source of stem cells are bone marrow stem cells (hematopoietic stem cells), stem cells derived from adipose tissue and bone marrow stromal cells (mesenchymal stromal stem cells). Bone marrow stem cells (BMSCs) and stem cells from adipose tissue have shown tissue regeneration having feature of periodontium, cementum and alveolar bone in experimental animal models [35,36,39]. Stem cells from dental origin have also been isolated and are classified into five types; dental pulp stem cells (DPSCs) [40], stem cells from exfoliated 

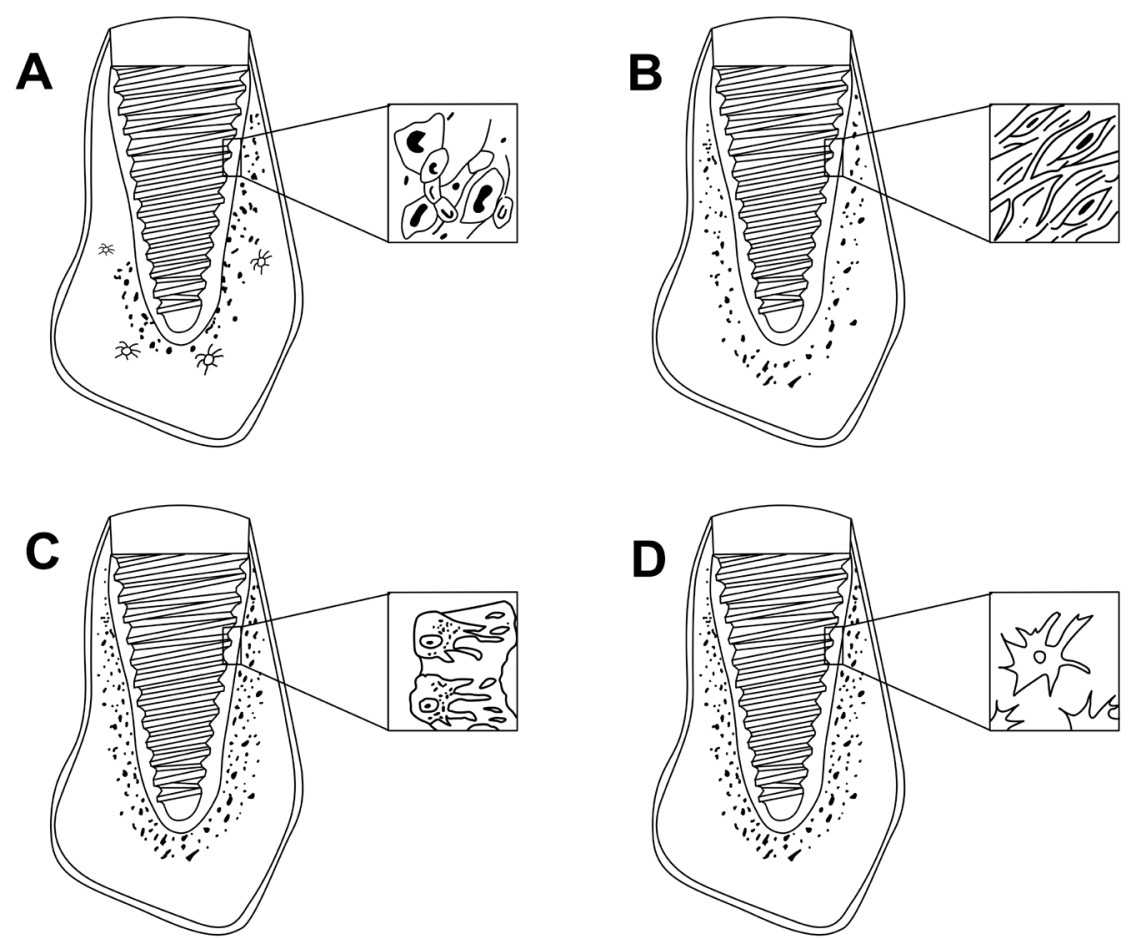

Figure 2. Healing events around endosseous dental implant: A- Formation of blood clot, B - Fibroblast and new capillaries, C- Osteoid formation, D- Mature bone.

deciduous teeth (SHED) [41], periodontal ligament stem cells (PDLSCs) [42], stem cells from apical papilla (SCAP) [43] and dental follicle progenitor cells (DFPCs) [44]. They all have mesenchymal stem cell properties and hence are capable of giving rise to various lineages of cells, like osteogeneic, chondrogeneic, adipogenic, myogenic and neurogenic cells [45]. Stem cells isolated from human periodontal ligament have been shown to give rise fibroblast like cells that may develop into adipocytes, osteoblasts-like, cementoblast-like cells in vitro and cementum-like and periodontal ligament- like tissue in vivo [42]. It has been reported that mesenchymal stem cells isolated from dental follicle can give rise to periodontal ligament like tissue [46]. Periodontal ligament regeneration in diseased tooth with periodontal pathology also employs progenitor cells for native tissue regeneration [47]. Scaffold based experiments in periodontally involved tooth have resulted in generation of PDL-like tissues in diseased areas [48]. However, exploration about the type of stem cells required for complete PDL regeneration is still insufficient.

\section{Approaches for periodontal regeneration}

There are many studies reported in literature which discusses periodontal regeneration of teeth in experimental animal subjects with periodontal pathology by using Guided tissue regeneration (GTR) membranes [49-52]. Further, Nayman et al. was successful in regenerating periodontium like tissues in periodontolly involved human tooth by using GTR membrane [53]. A crucial factor in GTR is the presence of adjacent healthy periodontal ligament tissue, from which the slow growing cells are allowed to repopulate the diseased site while the barrier membrane excludes unwanted tissues like fast growing gingival connective tissue and epithelium to take part in the healing process [54].

Recently, various attempts have been made by researchers to regenerate periodontium onto the surface of the implants. Broadly three types of approaches have been reported in the literature (Table 2).

\section{Regeneration of periodontium with residual root tip}

Various researcher tried to regenerate periodontium by placing implants in contact with residual healthy root tips (Figure 3A.) [5557]. Warrer et al. reported that regeneration of periodontium like tissue is possible in voids between alveolar bone and titanium implant surface when the implant is placed in contact with retained root tip [55]. Similar inference were also drawn by Guarnieri [56]. Buser [57] also reported similar experimental findings in humans as well as in monkeys respectively.

\section{Regeneration of periodontium with implant touching the root of adjacent tooth}

In this approach, the titanium implant touches the root of adjacent tooth or they are placed between the roots to allow the growth of periodontium onto it (Figure 3B). Experimental studies conducted by Jahangiri et al. [58], Urabe et al. [59], Rinaldi JC et al. [60] have concluded that cementum and periodontium like tissues were regenerated on the surface of implants when this approach was explored. However, no studies have been published on the dental health of teeth whose root(s) have been used as a source of contact in regeneration of periodontium on the titanium dental implant.

\section{Regeneration of periodontium with cultured cells}

Periodontal ligament has also been regenerated by using stem cells seeded in appropriate biodegradable scaffold (Figure 3C). Choi et al. [37], Marei et al. [36], Lin et al. [39], have reported that regeneration of periodontal tissue is possible by seeding pluripotent stem cells in various types of scaffolds and implanting it in vivo. Gault et al. had reported that cells isolated from periodontium could be co-cultured with titanium pins in bioreactor which could later be implanted in monkeys to successfully regenerate periodontium like structures [61]. Piattelli et al. reported that periodontal ligament like structure 
Table 2: Various work regarding regeneration of periodontium are listed in the following table.

\begin{tabular}{|c|c|c|c|c|c|c|c|c|}
\hline $\begin{array}{l}\text { Author and } \\
\quad \text { year }\end{array}$ & $\begin{array}{l}\text { Type of } \\
\text { Animal } \\
\text { subject }\end{array}$ & $\begin{array}{l}\text { Experimental } \\
\text { approach }\end{array}$ & $\begin{array}{c}\text { Tooth } \\
\text { selected }\end{array}$ & $\begin{array}{c}\text { Maxillary/mandibular } \\
\text { tooth }\end{array}$ & Type of Implant & $\begin{array}{l}\text { Post-operative } \\
\text { healing period }\end{array}$ & Histology & Conclusion \\
\hline $\begin{array}{c}\text { Warrer et al. } \\
1993[55]\end{array}$ & Monkeys & $\begin{array}{l}\text { Implant touching } \\
\text { the retained root } \\
\text { tip }\end{array}$ & $\begin{array}{c}\text { Premolars and } \\
\text { molars }\end{array}$ & Mandibular Tooth & $\begin{array}{l}\text { Self tapping titanium dental } \\
\text { implants }\end{array}$ & 3 months & $\begin{array}{c}\text { Contact area } \\
\text { showed cementum } \\
\text { and periodontium }\end{array}$ & $\begin{array}{l}\text { Formation of } \\
\text { periodontium and } \\
\text { cementum in voids } \\
\text { present between the } \\
\text { alveolus and surface } \\
\text { of implant }\end{array}$ \\
\hline $\begin{array}{c}\text { Jahangiri et al. } \\
2005[58]\end{array}$ & Beagle dogs & $\begin{array}{l}\text { Implant touching } \\
\text { the root of } \\
\text { adjacent tooth }\end{array}$ & Premolars & Maxillary tooth & HA coated titanium implants & 6 weeks & $\begin{array}{l}\text { Periodontium like } \\
\text { structures and } \\
\text { cementum are seen }\end{array}$ & $\begin{array}{c}\text { Formation of } \\
\text { periodontal like tissues } \\
\text { when implant touches } \\
\text { the adjacent tooth }\end{array}$ \\
\hline $\begin{array}{l}\text { Nyman S et } \\
\text { al.1982 [53] }\end{array}$ & Human & $\begin{array}{l}\text { Guided tissue } \\
\text { regeneration }\end{array}$ & Incisor & Mandibular tooth & N/A & 3 months & $\begin{array}{l}\text { New cementum } \\
\text { and principle fibres } \\
\text { of periodontal } \\
\text { ligaments like } \\
\text { tissue are seen }\end{array}$ & $\begin{array}{l}\text { GTR could be } \\
\text { used to regenerate } \\
\text { periodontium } \\
\text { in periodontally } \\
\text { involved tooth }\end{array}$ \\
\hline $\begin{array}{l}\text { Masaji U et } \\
\text { al.1999 [59] }\end{array}$ & Beagle dogs & $\begin{array}{l}\text { Implant touching } \\
\text { the root of } \\
\text { adjacent tooth }\end{array}$ & Premolar & Mandibular tooth & $\begin{array}{l}\text { Uncoated and coated } \\
\text { titanium implant } \\
\text { ( coated with HA) }\end{array}$ & 3 months & $\begin{array}{c}\text { HA coated } \\
\text { samples displayed } \\
\text { periodontium and } \\
\text { calcified cementum } \\
\text { like tissues }\end{array}$ & $\begin{array}{l}\text { Bioactivity of } \\
\text { implants influence } \\
\text { cell differentiation }\end{array}$ \\
\hline $\begin{array}{l}\text { Choi et al. } \\
2000[37]\end{array}$ & Dogs & $\begin{array}{l}\text { Implant cultured } \\
\text { with periodontal } \\
\text { ligament cells }\end{array}$ & & Mandibular tooth & $\begin{array}{l}\text { Titanium implant with } \\
\text { PDLSCs }\end{array}$ & & $\begin{array}{l}\text { Cementum and } \\
\text { collagen fibres }\end{array}$ & $\begin{array}{l}\text { Possible method } \\
\text { for periodontal } \\
\text { regeneration }\end{array}$ \\
\hline $\begin{array}{c}\text { Takata et } \\
\text { al.1995 [50] }\end{array}$ & Rat & $\begin{array}{l}\text { Giuded tissue } \\
\text { regeneration by } \\
\text { using occlusive } \\
\text { membrane }\end{array}$ & Molars & Mandibular tooth & Synthetic block of HA & 6-8 weeks & $\begin{array}{l}\text { Cementum and } \\
\text { collagen fibres }\end{array}$ & $\begin{array}{l}\text { PDLSCs can form } \\
\text { connective tissue } \\
\text { attachment on } \\
\text { denuded root surface } \\
\text { and non-dental } \\
\text { inorganic material } \\
\text { like HA block }\end{array}$ \\
\hline $\begin{array}{l}\text { Nyman S et } \\
\text { al.1982 [49] }\end{array}$ & Monkeys & $\begin{array}{l}\text { Guided tissue } \\
\text { regeneration }\end{array}$ & $\begin{array}{l}\text { Lateral } \\
\text { incisors, } \\
\text { canines }\end{array}$ & $\begin{array}{l}\text { Maxillary and mandibular } \\
\text { tooth }\end{array}$ & N/A & 6 months & $\begin{array}{l}\text { New cementum } \\
\text { with inserting } \\
\text { collagen fibers was } \\
\text { observed }\end{array}$ & $\begin{array}{l}\text { Periodontal ligament } \\
\text { cells possess the } \\
\text { ability to re-establish } \\
\text { connective tissue } \\
\text { attachment. }\end{array}$ \\
\hline $\begin{array}{l}\text { A Doğan et } \\
\text { al.2002 [51] }\end{array}$ & Dogs & $\begin{array}{l}\text { Guided tissue } \\
\text { regeneration }\end{array}$ & Premolars & Mandibular Tooth & N/A & 42 days & $\begin{array}{l}\text { Formation of } \\
\text { new connective } \\
\text { tissue attachment } \\
\text { with cementum } \\
\text { formation }\end{array}$ & $\begin{array}{l}\text { Regeneration in } \\
\text { furcation defects } \\
\text { by cell-seeding } \\
\text { technique may be } \\
\text { useful }\end{array}$ \\
\hline $\begin{array}{l}\text { H. Lang et al. } \\
1998[70]\end{array}$ & Mini pigs & $\begin{array}{l}\text { Cultured cells } \\
\text { with various } \\
\text { membranes }\end{array}$ & $\begin{array}{c}\text { Premolars and } \\
\text { Molars }\end{array}$ & $\begin{array}{l}\text { Maxillary and mandibular } \\
\text { tooth }\end{array}$ & N/A & $\begin{array}{c}\text { Assessed after } \\
10,30 \text { and } 90 \\
\text { days }\end{array}$ & $\begin{array}{l}\text { Formation of } \\
\text { cementum and } \\
\text { alveolar bone } \\
\text { leading to the } \\
\text { development of } \\
\text { new attachment } \\
\text { were observed }\end{array}$ & $\begin{array}{c}\text { Replantation of } \\
\text { cultured cells leads } \\
\text { to formation of new } \\
\text { cementum and bone, } \\
\text { which, in turn, leads } \\
\text { to formation of new } \\
\text { attachment. }\end{array}$ \\
\hline $\begin{array}{c}\text { Kawaguchi } \\
\text { H et al. } 2004 \\
{[69]}\end{array}$ & Beagle dogs & $\begin{array}{c}\text { Auto } \\
\text { transplantation of } \\
\text { MSCs in defects }\end{array}$ & & & N/A & 1 month & $\begin{array}{l}\text { Regeneration } \\
\text { of cementum, } \\
\text { periodontal } \\
\text { ligament and } \\
\text { alveolar bone }\end{array}$ & $\begin{array}{l}\text { Auto-transplantation } \\
\text { of bone marrow } \\
\text { mesenchymal stem } \\
\text { cells is a novel option } \\
\text { for periodontal tissue } \\
\text { regeneration. }\end{array}$ \\
\hline $\begin{array}{l}\text { Aukhil I et } \\
\text { al.1986 [71] }\end{array}$ & Beagle dogs & $\begin{array}{l}\text { Guided tissue } \\
\text { regeneration }\end{array}$ & Canines & Mandibular tooth & N/A & 3 months & $\begin{array}{c}\text { New connective } \\
\text { tissue attachment } \\
\text { was seen }\end{array}$ & $\begin{array}{l}\text { Root dentin contact } \\
\text { may be necessary } \\
\text { for progenitor cell } \\
\text { differentiation } \\
\text { into cells like } \\
\text { cementoblasts. }\end{array}$ \\
\hline $\begin{array}{l}\text { Akira } \\
\text { Miyashita et } \\
\text { al. } 2005 \text { [68] }\end{array}$ & Rats & $\begin{array}{l}\text { Implants placed in } \\
\text { extraction sockets }\end{array}$ & Molars & Maxillary tooth & Titanium dental implant & 21 and 28 days & $\begin{array}{l}\text { Cementum and } \\
\text { collagen fibres }\end{array}$ & $\begin{array}{c}\text { Placing implant } \\
\text { into socket with } \\
\text { periodontal ligament } \\
\text { leads to formation of } \\
\text { new connective tissue } \\
\text { attachment apparatus }\end{array}$ \\
\hline $\begin{array}{c}\text { Guarnieri R et } \\
\text { al.2002 [56] }\end{array}$ & Human & $\begin{array}{l}\text { Implant touching } \\
\text { the retained root } \\
\text { tip }\end{array}$ & Canines & Mandibular tooth & Titanium dental implant & 1 year & $\begin{array}{l}\text { A continuous layer } \\
\text { of cementum } \\
\text { adhering to the } \\
\text { implant and } \\
\text { innumerable } \\
\text { cementocytes }\end{array}$ & $\begin{array}{l}\text { Further studies are } \\
\text { warranted as only } \\
\text { cemental layer } \\
\text { without CT and blood } \\
\text { vessels in the PDL } \\
\text { space were formed }\end{array}$ \\
\hline
\end{tabular}




\begin{tabular}{|c|c|c|c|c|c|c|c|c|}
\hline $\begin{array}{c}\text { Parlar A et al. } \\
2005 \text { [67] }\end{array}$ & $\begin{array}{l}\text { Mongrel } \\
\text { dogs }\end{array}$ & $\begin{array}{l}\text { Custom-made, } \\
\text { titanium implant } \\
\text { was placed into } \\
\text { the center of } \\
\text { hollowed root }\end{array}$ & Canines & Maxillary tooth & Titanium implant & 4 months & $\begin{array}{l}\text { Presence of } \\
\text { connective tissue } \\
\text { layer between } \\
\text { implant and } \\
\text { dentinal wall }\end{array}$ & $\begin{array}{l}\text { Presence of } \\
\text { periodontal } \\
\text { tissue prevents } \\
\text { osseointegration }\end{array}$ \\
\hline $\begin{array}{l}\text { Marei MK et } \\
\text { al. } 2009 \text { [36] }\end{array}$ & Goat & $\begin{array}{c}\text { Implant covered } \\
\text { by scaffold with } \\
\text { Bone marrow stem } \\
\text { cells }\end{array}$ & Canines & Mandibular tooth & Titanium implant & $\begin{array}{l}10 \text { days and } 1 \\
\text { month }\end{array}$ & $\begin{array}{l}\text { Periodontal-like } \\
\text { tissue with newly } \\
\text { formed bone }\end{array}$ & $\begin{array}{c}\text { Undifferentiated } \\
\text { mesenchymal stem } \\
\text { cells can give rise to } \\
\text { periodontium and its } \\
\text { associated structures } \\
\text { in vivo }\end{array}$ \\
\hline $\begin{array}{l}\text { Rinaldi JC et } \\
\text { al } 2010 \text { [60] }\end{array}$ & Rats & $\begin{array}{l}\text { Implant touching } \\
\text { the root of tooth }\end{array}$ & Molars & Mandibular tooth & Titanium-mini implant & $\begin{array}{l}21,30,45,60 \\
90 \text { and } 120 \\
\text { days }\end{array}$ & $\begin{array}{l}\text { Cementum-like } \\
\text { layer in samples } \\
\text { subjected to } \\
\text { prolonged healing } \\
\text { time }\end{array}$ & $\begin{array}{c}\text { Cementogenesis } \\
\text { occurs in area where } \\
\text { there was a contact } \\
\text { between periodontium } \\
\text { and implant }\end{array}$ \\
\hline $\begin{array}{l}\text { Gault P et al. } \\
2010[61]\end{array}$ & Dogs & $\begin{array}{l}\text { PDL cells cultured } \\
\text { with titanium pins }\end{array}$ & & & Titanium pins & & $\begin{array}{l}\text { Ligament tissues } \\
\text { were demonstrated } \\
\text { in dogs }\end{array}$ & $\begin{array}{l}\text { Could be a possible } \\
\text { method for PDL } \\
\text { regeneration around } \\
\text { implant }\end{array}$ \\
\hline $\begin{array}{l}\text { Lin Y et al } \\
2010[39]\end{array}$ & Rats & $\begin{array}{l}\text { Implant covered } \\
\text { by scaffold with } \\
\text { rat periodontal } \\
\text { derived MSCs }\end{array}$ & Molars & Maxillary tooth & Titanium implant & $\begin{array}{l}8,12 \text { and } 18 \\
\text { weeks }\end{array}$ & $\begin{array}{c}\text { Collagen } \\
\text { fibers oriented } \\
\text { perpendicular to } \\
\text { the cementum } \\
\text { surface, resembling } \\
\text { naturally formed } \\
\text { PDL and Sharpey's } \\
\text { fibres }\end{array}$ & $\begin{array}{l}\text { PDL-derived MSCs } \\
\text { could potentially be } \\
\text { used to regenerate } \\
\text { autologous PDL } \\
\text { tissues on titanium } \\
\text { implants in vivo }\end{array}$ \\
\hline $\begin{array}{c}\text { Takamitsu } \\
\text { kano et al.2012 } \\
{[66]}\end{array}$ & Rats & $\begin{array}{c}\text { Titanium placed in } \\
\text { extraction socket } \\
\text { with and without } \\
\text { occlusion }\end{array}$ & Molars & $\begin{array}{l}\text { Maxillary and mandibular } \\
\text { tooth }\end{array}$ & $\begin{array}{l}\text { HA coated and non coated } \\
\text { titanium implants }\end{array}$ & $\begin{array}{l}\text { Histological } \\
\text { studies were } \\
\text { carried out after } \\
28 \text { days }\end{array}$ & $\begin{array}{c}\text { Periodontal } \\
\text { ligament like tissue } \\
\text { formed on the HA } \\
\text { coated implants } \\
\text { subjected to } \\
\text { occlusal loading }\end{array}$ & $\begin{array}{l}\text { Remnants of PDL } \\
\text { and occlusal loads } \\
\text { to the HA-coated } \\
\text { implants may induce } \\
\text { regeneration of PDL- } \\
\text { like tissue in the peri- } \\
\text { implant area }\end{array}$ \\
\hline $\begin{array}{l}\text { Buser D et al. } \\
1990[72]\end{array}$ & Monkeys & $\begin{array}{l}\text { Implant touching } \\
\text { the retained root } \\
\text { tip }\end{array}$ & & Mandibular tooth & Titanium implant & & $\begin{array}{l}\text { Cementing layers } \\
\text { with inserting } \\
\text { collagen fibres }\end{array}$ & $\begin{array}{l}\text { Possible method } \\
\text { for periodontal } \\
\text { regeneration around } \\
\text { dental implant }\end{array}$ \\
\hline $\begin{array}{l}\text { Buser D et al. } \\
1990[57]\end{array}$ & Monkeys & $\begin{array}{l}\text { Implant touching } \\
\text { the retained root } \\
\text { tip }\end{array}$ & & Mandibular tooth & $\begin{array}{c}\text { Hollow cylindrical implants } \\
\text { with titanium plasma- } \\
\text { sprayed }\end{array}$ & 1 year & $\begin{array}{l}\text { Layer of cementum } \\
\text { on the implant } \\
\text { surface and } \\
\text { periodontal } \\
\text { ligament with } \\
\text { collagen fibres } \\
\text { perpendicularly } \\
\text { oriented to the } \\
\text { implant surface }\end{array}$ & $\begin{array}{l}\text { Possible scope } \\
\text { for regeneration } \\
\text { of all components } \\
\text { of the periodontal } \\
\text { attachment apparatus }\end{array}$ \\
\hline $\begin{array}{l}\text { Caiazza S et } \\
\text { al.1991 [65] }\end{array}$ & Rabbit & $\begin{array}{l}\text { Implant placed } \\
\text { surgically in the } \\
\text { alveolus }\end{array}$ & & Mandibular tooth & $\begin{array}{c}\text { Modified titanium implant } \\
\text { with polymethylmethacrylate } \\
\text { and dacron }\end{array}$ & 3 months & $\begin{array}{c}\text { Complete } \\
\text { incorporation of } \\
\text { dacron filamentous } \\
\text { tissue }\end{array}$ & $\begin{array}{l}\text { New experimental } \\
\text { supporting element } \\
\text { has mechanical } \\
\text { behaviour similar } \\
\text { to PDL }\end{array}$ \\
\hline $\begin{array}{c}\text { Takata et } \\
\text { al.1994 [64] }\end{array}$ & Cat & $\begin{array}{c}\text { Implants placed in } \\
\text { root cavities }\end{array}$ & Canines & & $\begin{array}{c}\text { Bioactive } \\
\text { (HA,Bioglass),Bioinert } \\
\text { (titanium alloy, Zirconium) }\end{array}$ & & $\begin{array}{l}\text { Connective tissue } \\
\text { layer on bioactive } \\
\text { surface of implants }\end{array}$ & $\begin{array}{c}\text { Formation of } \\
\text { new connective } \\
\text { tissue attachment } \\
\text { is influenced by } \\
\text { bioactivity of the } \\
\text { materials. }\end{array}$ \\
\hline $\begin{array}{c}\text { Adriano } \\
\text { Piattelli et } \\
\text { al.1994 [62] }\end{array}$ & Landrace pig & $\begin{array}{c}\text { Implants placed in } \\
\text { healed sockets }\end{array}$ & Premolars & Mandible & Titanium implants & 3 months & $\begin{array}{l}\text { Formation of } \\
\text { mineralized tissue } \\
\text { with similarities } \\
\text { to cementum } \\
\text { and separated } \\
\text { from the bone by } \\
\text { periodontal-like } \\
\text { tissue }\end{array}$ & $\begin{array}{l}\text { Further studies are } \\
\text { warranted }\end{array}$ \\
\hline $\begin{array}{l}\text { Fulan Wei et } \\
\text { al. } 2013 \text { [63] }\end{array}$ & Swine & $\begin{array}{c}\text { Implants placed in } \\
\text { healed sockets }\end{array}$ & $\begin{array}{c}\text { Not } \\
\text { mentioned }\end{array}$ & Mandible & $\begin{array}{l}\text { PDLSCs sheet wrapping the } \\
\text { HA/Tricalcium Phosphate/ } \\
\text { Dental Pulp Stem Cells }\end{array}$ & 6 months & $\begin{array}{l}\text { PDL-like tissues } \\
\text { were generated } \\
\text { parallel to the } \\
\text { dentin-like matrix } \\
\text { structure in the } \\
\text { autologous group } \\
\text { and allogenic } \\
\text { group }\end{array}$ & $\begin{array}{l}\text { Possible way to } \\
\text { regenerate dentinal } \\
\text { tubule-like and } \\
\text { functional periodontal } \\
\text { ligament-like } \\
\text { structures.Further } \\
\text { studies are warranted }\end{array}$ \\
\hline
\end{tabular}



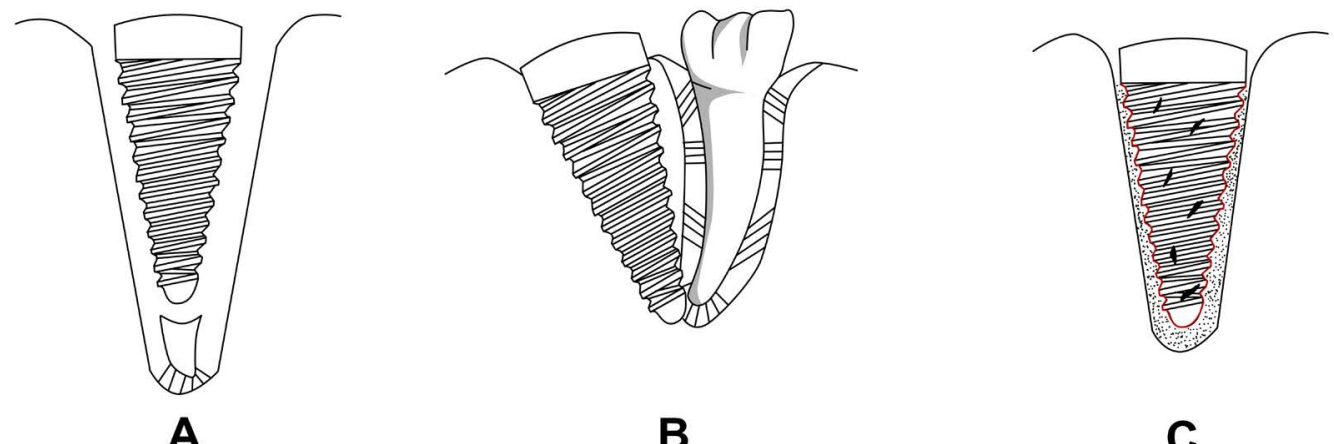

A

B

Figure 3. Various regenerative approaches of periodontium:A- Regeneration of periodontium with residual root tip, B- Regeneration of periodontium with implant touching the root of adjacent tooth, $\mathbf{C}$ - Regeneration of periodontium with cultured cells

could be regenerated when titanium implants are placed in alveolar sockets close to tooth buds [62]. Fulan Wei et al. reported that when periodontal ligament stem cells (PDLSCs) sheet was wrapped around hydroxyapatite/tricalcium phosphate ( HA/TCP) with dental pulp stem cells (DPSCs) and are placed in extraction socket, they give rise to periodontal ligament like tissue when examined histologically [63].

Takata et al. believed that bioactive materials such as HA and bioglass are better suited for regeneration of periodontium when compared to bioinert material like titanium [64]. Studies showed that implant made of titanium, poly(methylmethacrylate) and dacron implanted into alveolus of rabbit could give rise to attachment apparatus whose mechanical behaviour was comparable to periodontal ligament [65]. Authors found that periodontal ligament (PDL) like tissues could be induced on HA coated titanium dental implants when subjected to occlusal load in rats [66]. Reports suggests that placing custom-made, titanium implant in hollowed roots with narrow slits, give rise to growth of periodontium like tissue onto it [67].

Studies demonstrates that when titanium implants were placed in immediate extraction socket in rats, cementum and periodontal like fibres were formed with adequate mechanical strength [68]. Reports suggest that when stem cells were placed in alveolar bone defects there was a possibility of regeneration of periodontal tissues [69]. Study also demonstrates that replantation of cultured alveolar bone cells leads to formation of new cementum and bone, which, in turn leads to formation of new attachment [70].

\section{Periodontium and proprioception}

Proprioception is a type of sensory function of periodontium [73]. Proprioception, also called kinesthesia, "involves awareness of the spatial and mechanical status of the musculoskeletal framework" [74]. The afferent nerve fibres (component of peripheral nervous system) concerned with proprioception are broadly classified morphologically as free, naked and non-encapsulated endings. The free nerve endings are further classified as simple (e.g. skin), elaborate ( e.g. golgi tendon organ) and more elaborate (e.g. muscle spindle) nerve endings [75]. Functionally, they are divided into exteroceptors ( receives stimuli from external origin mainly light pressure and touch), interoceptors (receives stimuli from visceral origin), proprioceptors (receives stimuli from joints, tendons, skeletal muscles, body wall etc.) [75].

Upon histological examination, PDL displayed two types of nerve fibres; thick fibres with spindle like endings in the periphery, probably concerned with tactile and pressure sensation and fine nerve fibres in the deeper region possibly relaying pain sensation [76]. The same authors in another article discussed about the end organs found in the PDL of cats which were "spindle like in shape and were formed by nerve fibres twisted like a spiral spring. At intervals on the convolutions there were rounded thickenings" [77]. Reports also suggest that in guinea pigs upper two/third of the root contains fine nerve endings for pain sensations while lower third consists of nerve fibres ending in club-like fashion probably concerned with pressure and tactile sensation [78]. Allgood suggested three types of PDL receptors- (1) pressoreceptors related to consciousness (2) pressoreceptors unrelated to consciousness and (3) nociceptors [79]. It was also claimed that mechanoreceptors in periodontium are mainly two types of nerve endings which relay precise information to CNS regarding pressure [80]. Further, it was found that majority of nerves that relay pain are located in the pulp and those conduct pressure sensation are present in periodontal membrane [81]. Studies have shown that periodontal sensory units fire upon mechanical stimulation $[82,83]$ suggesting that they are responsive to tactile or pressure stimuli $[81,84]$. Authors further suggests that the impulses were originated purely from periodontal ligament because registration of the impulse continued even after removal of dental pulp $[81,85]$.

Recent studies have revealed that the Ruffini endings categorized as low-threshold, slowly adapting, type II mechanoreceptors are the primary mechanoreceptors in the periodontal ligament [86]. In the periodontal ligament Ruffini endings, the axon terminals have finger like projections called microspikes or axonal spikes, which invest into the surrounding tissue to detect the deformation of collagen fibres.[86]

The terminology that has been used in discussing mechanoreceptors has varied among authors. Freeman and Wyke distilled a number of reports and condensed the mechanoreceptors present in joints into four types [87] Table 3 .

Type II and Type III mechanoreceptors in particular are believed to be linked to one's sense of proprioception [89]. Very small forces applied to the tooth is registered and identified by the receptors present in the periodontium. Studies have shown that inserting very thin metal foil $(10-30 \mu \mathrm{m})$ during occlusion can be identified accurately. Micromotion of the tooth as low as in the range of 1-3 microns activates mechanoreceptors. Furthermore, if a particle of unregistered or unknown consistency is detected during mastication, the mandibular chewing movement is arrested reflexively. Later, temporomandibular joint (TMJ), masticatory muscles, etc. alters the mandibular chewing movement into mandibular opening movement [90] Figure 4.

Mechanoreceptors richly innervates the perodontium and their soma are located either in Trigeminal ganglion (TG) or in Mesencephalic 


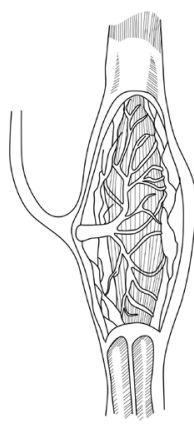

A

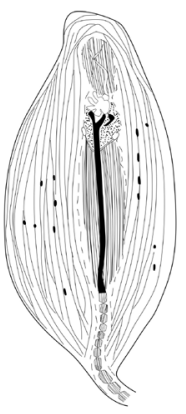

B

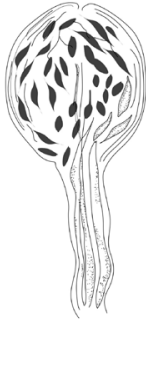

C

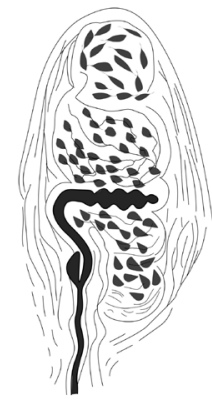

D

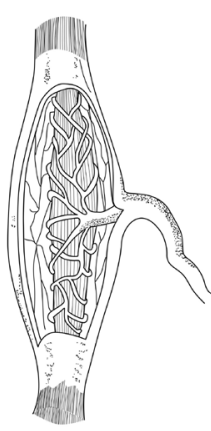

E

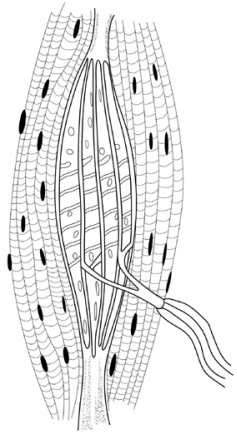

$\mathbf{F}$

Figure 4. Sensory receptors: A- Golgi tendon organ, B- Corpuscle of Pacini, C-End bulb of Krause, D- Meissner corpuscles, E- Corpuscle of Ruffini, F-Muscle spindle, (adapted from [88]).

Table 3. Various feature of mechanoreceptors is listed in the table below, (adapted from [87]).

\begin{tabular}{|c|c|c|c|c|c|c|}
\hline Eponymous name & Type & Morphology & Location & $\begin{array}{l}\text { Diameter of afferent } \\
\text { fibres(microns) }\end{array}$ & Average size(microns) & Figures \\
\hline Ruffini, Golgi-Mazzoni & I & $\begin{array}{l}\text { Globular, bulbous or ovoid } \\
\text { corpuscle with thin capsule }\end{array}$ & $\begin{array}{l}\text { Periosteum } \\
\text { joint capsule, } \\
\text { tendons } \\
\text { ligaments, }\end{array}$ & $5-8$ & $100 \times 40$ & E, B \\
\hline $\begin{array}{l}\text { Pacini, Krause, Vater- } \\
\text { Pacini }\end{array}$ & II & $\begin{array}{c}\text { Cylindrical or conical } \\
\text { corpuscle with thick } \\
\text { concentric laminated layers }\end{array}$ & Joint capsule & $8-12$ & $280 \times 120$ & $\mathrm{~B}, \mathrm{C}, \mathrm{B}$ \\
\hline Golgi,Golgi-Mazzoni & III & $\begin{array}{c}\text { Fusiform corpuscle with thin } \\
\text { capsule }\end{array}$ & Ligaments, tendons & $13-17$ & $600 \times 100$ & $\mathrm{~A}, \mathrm{~B}$ \\
\hline Not- reported & IV & $\begin{array}{l}\text { Unmyelinated free nerve } \\
\text { endings }\end{array}$ & $\begin{array}{l}\text { Ligaments, tendons, } \\
\text { blood vessels } \\
\text { joint capsule, } \\
\text { periosteum }\end{array}$ & $0.5-5$ & $0.5-1.5$ & - \\
\hline
\end{tabular}

(MS) trigeminal nucleus of central nervous system (CNS). TG and MS are different in central connections, functional significance and threshold levels but are similar in detecting stretch of periodontal ligament induced by micro or macromotion of tooth [91]. Studies have shown different distribution of MS and TG receptors in PDL of cat. Distribution of mechanoreceptors were found to be homogeneous and heterogeneous in the middle and apical portion of cat's tooth with their soma in TG and MS respectively [92]. Authors agreed by and large that periodontal ligament have two types of mechanoreceptors, rapidly adapting and slowly adapting. Some authors claimed that the third type of mechoreceptors viz. with spontaneously discharging and slowly adapting capability could be credited in part to cutting the sympathetic efferents [93]. It was claimed that surrounding peripheral tissues are loosely fit to rapidly adapting receptors resulting in easy gliding of tissues when forces applied. They are known to conduct signals from initial contact with food or antagonistic teeth. While slowly adapting receptors are firmly integrated to the surrounding tissues and are known for localizing of tooth being stimulated, direction of stimulus, intensity and pressure applied to tooth etc. Interestingly, when forces just above threshold are applied to slowly adapting receptors, they behaves like rapidly adapting receptors.

In another study, inferior alveolar nerve from nine cats were used for studying 127 periodontal mechanoreceptors (PDM). 105 PDM were found to be responded to both phasic and sustained component of force applied to crown and are classified under slowly adapting PDM. 22 PDM responded while the force is applied but did not fire during a sustained force and were classified as rapidly adapting PDM. Of these 127 PDM, 7 were rapidly adapting receptors and were near to the fulcrum than to apex, apical 3rd of the ligament contains 23 slowly adapting receptors and 30 were found to be located in the labial part of the PDL [93]. Transmission of tactile sensation, pressure and pain are supplied by sensory fibres of periodontium via the trigeminal pathway into their trophic centre in trigeminal ganglion. Proprioceptive nerves have their tropic centre placed centrally i.e. in mesencephalic nucleus of CNS. Nerve bundles follows the porous alveolar bone and blood vessels, pass into the PDL from the peri-apical area and are divided into single myelinated fibres which looses their myelin sheath and ends in neural terminals.

\section{Osseoperception and dental implants}

Different author claims that endosseous titanium dental implants give rise to a form of "weak alternate sensation" when they are subjected to mechanical stimulation which they termed as osseoperception. Proprioception and osseoperception are different entity as in later no periodontal mechanoreceptors are involved. We now introduce the concept of osseoperception briefly.

Dental caries and periodontal diseases are among the primary cause of tooth decay, which is followed by extraction for preparation of prosthetic treatment [94]. Loss and damage of a large number of exteroceptors occurs during tooth extraction leading to impaired sensory perception and feedback, which tune the motor control for proprioception of stomatognathic system including mandibular movements [95]. The level of evidence indicate that dental implants are among the best option for treating edentulous conditions and prevents its associated complications [96]. However, patients with osseointegrated implants supported prosthesis displayed impairment of fine motor control of the mandible because of loss of afferent impulse from mechanoreceptors present in the PDL. Surprisingly, mechanical stimulus of osseointegrated implants in the jaw bone still elicits response [95,97-104]. Amputation of tooth along with intra- 
dental and periodontal mechanoreceptors changes the sensory-motor coordination and results in faulty occlusal forces in masticatory system. Osseointegrated dental implants lack periodontal mechanoreceptors in peri-implant tissue which conducts tactile sensory input to the central nervous system (CNS), and are thought to play a key role in sensory discriminative capabilities and in the control of jaw functions in dentate individual [100].

Complete edentulous jaw restored with full denture demonstrates only partial function and hence is a compromised substitute when compared to implant supported prosthesis which have improved sensitivity directionally with better oral stereognosis [100,105]. Furthermore, evidence suggests that patients with implant supported prostheses displayed enhanced tactile discriminative capabilities and improved motor co-ordination compared to those who wore complete dentures. The detection of these unknown receptors responsible for this alternate "bony-perception" could probably be done by using somatosensory evoked potentials [101].

In a recent conference this alternate sensation named as 'osseoperception' was defined as "a change in central neural processing in maintaining sensorimotor function” [106]. Klineberg et al. also defined it as "the sensation arising from a mechanical stimulation of bone anchored prosthesis, transduced by mechanoreceptors that may include those located in muscle, joint, mucosal and periosteal tissues" [106]. Jacobs et al. stated that "clinical observations on patients with oral implants, have confirmed a special sensory perception skill. The underlying mechanism of this so-called 'osseoperception' phenomenon remains a matter of debate, because extraction of teeth involves elimination of the extremely sensitive periodontal ligaments while functional reinnervation around implants is still uncertain.” [99]. This findings may be attributed to the presence of some alternate peripheral feedback pathways to the sensory cortex coupled with receptors present in the periosteum/bone and has been termed as "osseoperception" described for both skeletal and dental osseointegrated implants [95]. The term 'Osseoperception' is defined by Yan $\mathrm{C}$ et al. as "the ability to identify kinesthetic sensation without the input from periodontal mechanoreceptors. This sensation is generated from the temporomandibular joint, masticatory muscle, mucosa, and periosteum, and provides sensory and motor information related to mandibular movements and occlusion" [107]. Klineberg defined osseoperception as "depending on central influences from corollary discharge from cortico-motor commands to jaw muscles, and contributions from peripheral mechanoreceptors in orofacial and temporomandibular tissues"[100].

Sensory discrimination in the orofacial region are of two typespassive discrimination and active discrimination. Periodontal mechanoreceptors determines passive discrimination and assessed by the application of definite and guided forces onto tooth surface. Active discrimination involves a number of mechanoreceptors present in the tooth, periodontium, jaw muscles, temporomandibular joints capsules and ligaments. It could be assessed by placing objects between the teeth. Both of these are age dependent and gradually decreases with increasing age [108-111]. Tests have revealed that passive discriminatory abilities are 10x higher in osseointegrated implants than that of natural teeth. (3.4 N and 0.3 N, respectively). Jacobs and van Steenberghe in 1993 reported that the osseointegrated implant threshold to be 50x higher than that of natural teeth [109]. Awareness of static and dynamic jaw position and forces for contraction of jaw muscles includes oral kinaesthetic and proprioceptive sensations.

It had been claimed that there are mainly two mechanism used by CNS for obtaining information regarding the position and movements of jaw and muscle contractions. The first is probably an input from Golgi tendon organs (GTOs) along with corollary discharge associated with jaw closing muscles is thought to be important in the sensation of voluntary biting. The second mechanism involves mechanoreceptors activated during different jaw movements. The input gives information about oral kinesthetics in relation to various jaw function and different contacts of opposing artificial tooth. These receptors are located in temporomandibular joint (TMJ), muscle, cutaneous, mucosal, and/or periosteum and provides mechanosensory information. It has also been claimed that although remnants of PDL mechanoreceptors are present in the peri-implant area, they do not contribute to osseoperception [100]. Presently, we have very little understanding of the neural inputs and pathways describing kinaesthetic perception in patients with implants (Table 4 and 5).

Table 4: Various theories of osseoperception.

\begin{tabular}{|c|c|c|}
\hline Author & Year & Theory \\
\hline Linden and Scott. [92] & 1989 & Suggests that periodontal receptors remains in the bone even after tooth extraction contributing to osseoperception \\
\hline Bonte B et al. [112] & 1993 & Proposes that neural fibres reinnervates when implants are subjected to control loading leading to osseoperception \\
\hline Klineberg I, Murray G. [100] & 1999 & Temporomandibular joint receptors take up the function in absence of periodontal receptors and performs osseoperception \\
\hline Van Steenberghe D et al. [99] & 2006 & Periosteal receptors take up the function in absence of periodontal receptors and performs osseoperception \\
\hline Weiner S et al. [113] & 2004 & Adjacent bone surrounding the implant contains nerve fibres which contributes to osseoperception \\
\hline Rowe et al. [114] & 2005 & Pacinian corpuscles may act as osseoreceptors located in the periosteum but further studies are warranted. \\
\hline
\end{tabular}

Table 5: Contribution of various mechanoreceptors in osseoperception of jaw.

\begin{tabular}{|c|c|c|c|}
\hline Type of mechanoreceptors & Anatomical location & Specifications & Functions \\
\hline (1) Joint mechanoreceptors [115-117] & $\begin{array}{c}\text { Joints like Temporomandibular joints and } \\
\text { others }\end{array}$ & $\begin{array}{l}\text { Low threshold (high-sensitive) } \\
\text { mechanoreceptors }\end{array}$ & $\begin{array}{l}\text { Joint receptors in TMJ acts as limited range } \\
\text { receptors, others concerned with protective } \\
\text { reflex }\end{array}$ \\
\hline $\begin{array}{l}\text { (2) Muscle mechanoreceptors [116,118-120] } \\
\text { (a)Golgi Tendon Organs (GTO) } \\
\text { (b) Muscle spindles }\end{array}$ & $\begin{array}{l}\text { (a) Musculo-tendinous junction, arranged in } \\
\text { series with extrafusal muscle fibres. } \\
\text { (b) Belly of all skeletal muscles and arranged } \\
\text { in parallel with extrafusal muscle fibres. }\end{array}$ & $\begin{array}{l}\text { (a) High and low threshold } \\
\text { mechanoreceptors. } \\
\text { (b) Low threshold (high }- \text { sensitive) } \\
\text { mechanoreceptors }\end{array}$ & $\begin{array}{l}\text { (a) Senses pulling of muscle fibres } \\
\text { (b)Provides information to CNS regarding } \\
\text { length of muscle and rate of change of } \\
\text { muscle length etc. }\end{array}$ \\
\hline (3)Cutaneous mechanoreceptors. [121-125] & Skin (Hairy and glabrous) & $\begin{array}{l}\text { Rapidly adapting and slowly adapting (type I } \\
\text { and type II) mechanoreceptors }\end{array}$ & $\begin{array}{c}\text { Relay information of kinaesthetic perception } \\
\text { and skin deformation }\end{array}$ \\
\hline (4) Mucosal mechanoreceptors $[110,126]$ & Mucosal lining & Low threshold (high -sensitive) & Contributes to mucosal sensation \\
\hline (5) Periosteal mechanoreceptors [83] & Periosteum & Low threshold (high sensitive) & Role in sensing periosteal deformation \\
\hline
\end{tabular}




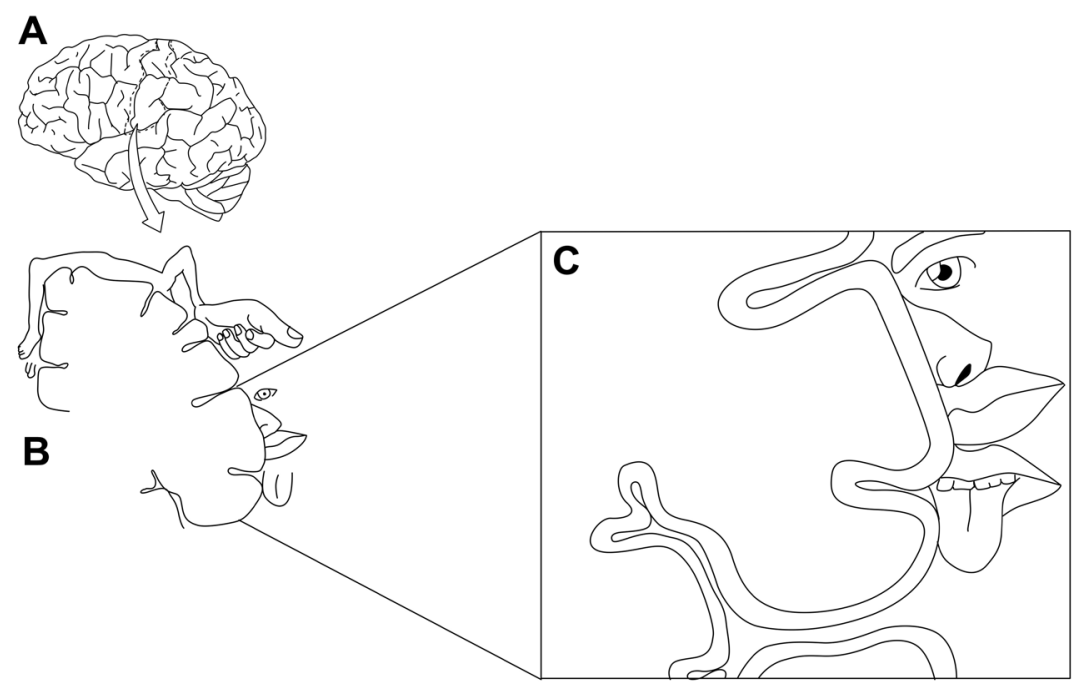

Figure 5. A- Primary somatosensory cortex, B- Sensory homunculus, C- Representation of oro-dento-facial region in sensory homunculus, (adapted from [128, 130]).

\section{Oral sensations and somatosensory cortices}

The sensory fibres originates from ophthalmic, maxillary and mandibular division of trigeminal nerve and inserts into trigeminal ganglion present in the middle cranial fossa. The fibres later ends at thalamus and cortex passing via trigeminal nuclei present at the level of pons in the brain stem [127]. All sensory inputs from these fibres are integrated and processed in somatosensory cortex which could be primary (S1) present in the lateral postcentral gyrus of parietal lobe in human brain or secondry (S2) present in upper part of sylvian fissure [128,129]

\section{Representation of orofacial somatosensory inputs in Central Nervous System (CNS)}

In 1937, Penfield and Boldrey published a paper comprising a physical representation of different anatomical parts in the human brain [130]. They named the map as cortical homunculus. There are two types of cortical homunculus; sensory and motor $[128,130]$. In this review we will be discussing very briefly about sensory homunculus; especifically the area which represents oro-dento-facial inputs (Figure 5).

It had been claimed by Penfield and others that cortical representation of the tooth was located superior to that of the tongue and inferior to that of the lip in somatosensory cortex $[128,130]$. Miyamoto et al. in 2006 studied the human brain by using fMRI and concluded that the teeth was represented in between the tongue (above) and lip (below) [131]; which was in accordance with the sensory homunculus proposed by Penfield. However, there was an overlap in the middle and caudal regions in postcental gyrus. This change in response from the cranial to caudal region could probably be due to integration of various oral tissues [131]. Further it is belived that primary somatosensory cortex (S1) comprises of Brodmann's areas $1,2,3 \mathrm{a}$ and $3 \mathrm{~b}[132,133]$. Brodmann's area 1 occupies the top part of postcentral gyrus. The cranial border of the Broadmann's area 3a is in the nadir of the central sulcus, followed by $3 b, 1$ and 2 which ends in the nadir of post central sulcus respectively $[132,133]$. Area 1 and $3 b$ receives primarily cutaneous afferents, and areas 2 and 3a receives more deep and proprioceptive inputs [133]. Secondary somatosensory cortex (SII) is believed to perform higher order functions including multisensory integration, memory, attention and learning [134]. Although advanced neuroimaging in humans for high resolution cortical somatosensory mapping is possible, it is difficult to provide stimulation in precise and controlled manner on specific oral tissues in functional magnetic resonance imaging (fMRI) environment [135].

Studies (although limited) have reported that CNS has got extensive representation of orofacial inputs like muscle GTO present in TMJ, periodontal mechanoreceptors, mucosal mechanoreceptors and have been demonstrated at various level of afferent somatosensory pathway including primary somatosensory cortex (S1) etc. [124,136138]. It had been suggested that these inputs could be used in muscle coordination for deglutition and chewing [139], precise control of facial and mandibular movements [140], reflexes [116] perceptual functions of oral kinaesthesia, oral stereognosis and tactile perception. [141,142]. Reports claimed that contribution of an elaborate cortical representation of cutaneous, mucosal, periosteal and deep somatosensory afferent can provide perceptual experiences associated with kinaesthetic sensibilities even in absences of PDL mechanoreceptors [100].

Information from mechanoreceptors are transmitted through somatosensory afferent pathways with high synaptic security and is represented in ventroposterolateral (VPL) thalamus and somatosensory cortex. Hence, in the absence of periodontal input, there is the possibility for adequate somatosensory information within the orofacial area, leading to kinesthetic and tactile perception and motor control of jaw and orofacial structures [143]. Reports suggests that specific somatosensory information is allowed to be transmitted to the cortex and hence leads to selective filtration of somatosensory stimuli [144]. Different types of stimuli are registered from dentate, implant supported and complete denture restored patients. The brain registers somatosensory input from implant supported prosthesis that will be different from that occurring from dantate individuals or from complete denture restored patients. It is believed that areas in somatosensory cortex in brain concentrate in these new specific sensory inputs and evolves to this new intra-oral environment [145].

Findings suggest that recent habits modify the details of representation of body surface in somatosensory cortical areas $[146,147]$. It has also been suggested by various studies that implants induces plastic changes in the somatotopic maps in the face motor and somatosensory cortical regions. These plastic behaviour tends to accommodate the new prosthesis in optimal functional status depending on oro-dental features and treatment standard [100]. 


\section{Detection and measurement methods for afferent activity of oral cavity}

The methods are broadly divided into neurophysiological and psychophysical methods.

\section{Neurophysiological methods}

Neurophysiological methods like trigeminal somatosensory evoked potentials (TSEPs), functional magnetic resonance imaging (fMRI), magnetoencephalography (MEG), functional near-infrared spectroscopy (fNIR or fNIRS) could be used for detection of oral tactile sense perceptions.

\section{Trigeminal somatosensory evoked potentials (TSEPs)}

Trigeminal somatosensory evoked potentials (TSEPs), a noninvasive technique is used for registering electroencephalographic signals involving trigeminal nerve. Because of low amplitude signal and high amount of electrical signal, averaging improves noise to signal ratio. Results may be misrepresented due to high muscle activity and salivation in orofacial region [148]. TSEPs can be induced placing electrodes in intradentinal or intrapulpal, [149] periodontal ligament, [150] gingiva [151] and lower lip [152].

\section{Functional magnetic resonance imaging, (fMRI) or microneurography}

Functional magnetic resonance imaging (fMRI) is a noninvasive and safe technique for visualization of the activation of brain during cognitive tasks. The method depends on measurement of Blood Oxygen Level Dependent (BOLD) signal. By hemodynamic response, blood flows to active neurons at greater rate than inactive neurons and are thus visualized.

Recently, study demonstrated that osseointegrated maxillary implants upon mechanical stimulation activates cortical somatosensory areas which may possibly provide the explanation of osseoperception. The group inferred that dental implant substituting a natural tooth induces plasticity in CNS as represented by the difference in cortical network when stimulating either the implant or natural tooth precisely at same anatomical location [104]. Hence, a hypothetical representation of the prosthesis in the cerebral cortex is established leading to enhanced adaptation to motoneuron pool for trying to compensate for natural physiological function. The inhibitory reflex of masseter muscle in partially edentulous jaw is elicited in implant supported prosthesis with elevated threshold responses when subjected to mechanical stimuli. However, this "silent period" was not seen in fully edentulous patients. The probable reason for this could be the activation of distant neural receptors present in other tooth [153-156].

\section{Magnetoencephalography (MEG)}

Magnetoencephalography (MEG) non-invasively measures the magnetic field generated due to the excitatory postsynaptic electrical activity of neurons in the living brain by using highly sensitive superconducting sensors viz.superconducting quantum interference device (SQUID). A magnetically shielded room houses the equipment, and diminish the interferences. Nakahara et al. using MEG showed S1 represented separate cortical areas for lips and tongue, with no clear separate area for gingiva [157]. Kubo et al. used electrical stimulation on tooth pulp and recorded the results with MEG [158]. MEG was also used by Bessho et al. for studing three separate areas in hard palate [159] etc.

\section{Functional near-infrared spectroscopy (fNIR or fNIRS)}

Functional near-infrared spectroscopy (fNIR or fNIRS) is a noninvasive method for quantification of chromophore concentration in tissues mainly the chromophore haemoglobin $(\mathrm{Hb})$ present in microcirculation (vessels $<1 \mathrm{~mm}$ in diameter) in the brain. Deoxy-Hb and $\mathrm{Oxy}-\mathrm{Hb}$ displays differences in absorption spectra which results in the measurement of relative changes in haemoglobin concentration. The cerebral blood flow was studied by Shimazaki et al. by using fNIR [160]. He used vibrotactile stimulation for various teeth and found out that apart from stronger response of molars compared to other tooth, the spatial resolution was insufficient for arriving at a conclusion Table 6 .

\section{Psychophysical evaluation}

Psychophysical evaluation includes the study of sensation/ perception and their respective influence when subjected to physical stimuli. Methods chiefly include threshold measurement, ideal observer analysis, and signal detection theory. For threshold level test, subjects are instructed to identify the pure stimulus from background noise [164]. Test are also carried out to verify if the threshold is active or passive. In passive threshold test, stimulation are passively applied onto the tooth surface or implant to stimulate mechanoreceptors present in periodontium or periosteum respectively [165]. In active threshold measurement, objects of different size are placed between antagonistic teeth or implants and participants are asked to manipulate those objects and report their sensations [166]. In this process, the tactile function of various mechanoreceptors from periosteum, mucosa, skin, muscle and periodontium (in case teeth is present) could be studied [142]. In humans passive threshold and active threshold is $60 \mathrm{x}$ and $6 \mathrm{x}$ higher for dental implants than natural teeth [110]. It has also been reported that one staged mandibular implants exhibited unchanged threshold during the healing phase in contrast to immediately loaded implants that showed enhanced passive tactile sensibility $[167,168]$.

\section{Stereognosis}

Stereognosis (haptic perception or tactile gnosis) is the ability to identify and discriminate various forms. It depends upon memory and intact somatic sensory system. Both, central analysis and peripheral receptors are involved [169]. It is seen to be developed best in blind people. Oral sensory function changes with loss of tooth. It was found in dentate individuals that stereognostic ability decreases approximately $20 \%$ when bilateral mandibular block is given [170]. Further, natural teeth showed better stereognostic ability than patient with full denture $[169,170]$. Lundqvist reported patients, that were rehabilitated with oral implants showed improvement with stereognostic ability [166]. Stereognosis represents an overall sensor ability rather than identifying any particular group of mechanoreceptors.

\section{Conclusion}

Dental implants with functional periodontium is a distinct possibility in near future, as can be inferred from the extensive work reviewed in this paper. Other options like implanting tooth bud into jaw bone which later give rise to functional tooth has been explored but proper morphology of tooth and its occlusion etc. remains a massive challenge. Presently, it seems that modification of titanium dental implants having proprioception is the closest possible alternative to natural tooth, however to achieve this, inputs from implantology, neural sciences to biomaterials along with better design of the implants are warranted. 
Table 6. Various studies upon stimulation of oral tissues by employing various neuroimaging techniques are listed in the table below.

\begin{tabular}{|c|c|c|c|c|}
\hline Author and year & Region & Type of stimulation & Imaging/Detection modelaties & Cortical projection/Analysis \\
\hline Nakahara et al. (2004) [157] & Gingiva,lip and gum & Electrical stimulation & MEG & $\begin{array}{l}\text { S1 showed separate cortical areas for lip } \\
\text { and tongue, no separate area for gum }\end{array}$ \\
\hline Miyamoto et al. (2006) [131] & Lips, tongue and teeth & Mechanical stimulation & fMRI & $\begin{array}{l}\text { Postcentral gyrus showed two gradient. } \\
\text { From primary towards higher processing } \\
\text { a cranio-caudal gradient was followed. }\end{array}$ \\
\hline Raab WH et al.(1991) [151] & Tooth & Mechanical stimuli & EEG & $\begin{array}{l}\text { Interpretation of SEP-PA revealed } \\
\text { change in perception following } \\
\text { repeated periodontal stimulation at } \\
\text { different rates. }\end{array}$ \\
\hline Bessho et al., (2007) [159] & Hard palate( 3 regions) & Electrical stimulation & MEG & Merged region in $\mathrm{S} 1$ \\
\hline Kubo et al. (2008) [158] & Tooth pulp & Electrical stimulation & MEG & Specific region in $\mathrm{S} 1$ \\
\hline Chatrian GE (1982) [149] & Tooth & Electrical pulse & Questionnaires & $\begin{array}{l}\text { Pulp can relay other sensations apart } \\
\text { from nociception }\end{array}$ \\
\hline Ettlin et al. (2004) [161] & Teeth & Vibration & fMRI & $\begin{array}{l}\text { Activation of motor and insula bilaterally. } \\
\text { No significant activation of S1 }\end{array}$ \\
\hline MH Bennett et al. 1980 [151] & Gum & Electrical stimulation & Triphasic wave & $\begin{array}{l}\text { Muscle potentials did not significantly } \\
\text { contribute to the characteristic response. }\end{array}$ \\
\hline Jantsch et al. (2005) [162] & Teeth and hand & Mechanical stimulation & fMRI & $\begin{array}{l}\mathrm{S} 1 \text { is activated bilaterally for tooth and } \\
\text { contralaterally for hand respectively. }\end{array}$ \\
\hline Barker GR et al. (1980) [152] & $\begin{array}{l}\text { Lip overlying the } 1^{\text {st }} \text { premolar/ } \\
\text { adjacent gingival margin }\end{array}$ & Electrical stimulation & Triphasic wave & $\begin{array}{l}\text { Increase in latency period was } \\
\text { associated with sensory impairment }\end{array}$ \\
\hline Guest et al. (2007) [163] & Oral cavity & Thermal stimulation & fMRI & $\begin{array}{l}\text { Bilateral activation of the } \\
\text { somatosensory cortex }\end{array}$ \\
\hline Shimazaki et al. (2012) [160] & Teeth & Vibrotactile stimulation & fNIR & $\begin{array}{l}\text { Insufficient spatial resolution to reach a } \\
\text { definite conclusion }\end{array}$ \\
\hline Habre-Hallage et al. (2012) [104] & Teeth, endosseous implant & Mechanical stimulation & fMRI & Bilateral activation of S1 and S2 \\
\hline
\end{tabular}

\section{Funding source}

Healthcare Consortium, IITB

\section{Conflict of interest}

The authors declare that they have no conflict of interest.

\section{Foot note}

1 Bellare Jayesh, Das Siddhartha and Soni Vivek P, Application for "Proprioceptive endosseous root-form dental implants," Indian Patent applied on March 9th, 2017.

\section{References}

1. Selwitz RH, Ismail AI, Pitts NB (2007) Dental caries. The Lancet 369: 51-59.

2. Tallgren A, Lang BR, Miller RL (1990) Longitudinal study of soft-tissue profile changes in patients receiving immediate complete dentures. The International Journal of Prosthodontics 4: 9-16.

3. Compagnon D, Woda A (1991) Supraeruption of the unopposed maxillary first molar. $J$ Prosthet Dent 66: 29-34.[Crossref]

4. N'gom PI, Woda A (2002) Influence of impaired mastication on nutrition. J Prosthet Dent 87: 667-673.[Crossref]

5. Bodic F, Hamel L, Lerouxel E, Baslé MF, Chappard D (2005) Bone loss and teeth. Joint Bone Spine 72: 215-221.[Crossref]

6. Shillingburg, HT, Hobo S, Whitsett LD, Brackett SE (1997) Fundamentals of Fixed Prosthodontics (eds.,) Learning 10: 40.

7. Gable TO, Kummer AW, Lee L, Creaghead NA, Moore LJ (1995) Premature loss of the maxillary primary incisors: effect on speech production. Asdc J Dent Child 62: 173-179.[Crossref]

8. AbrahamCM (2014) Suppl 1: A Brief Historical Perspective on Dental Implants, Their Surface Coatings and Treatments, The open dentistry journal 8:50.

9. Brånemark PI (1983) Osseointegration and its experimental background. J Prosthet Dent 50: 399-410.[Crossref]

10. Adell R, Lekholm U, Rockler B, Brånemark PI(1981)A 15-year study of osseointegrated implants in the treatment of the edentulous jaw. Int J Oral Surg 10: 387-416.[Crossref]
11. Weiss C (1986) Tissue integration of dental endosseous implants: description and comparative analysis of the fibro-osseous integration and osseous integration systems, The Journal of Oral Implantology 12: 169.

12. Misch CE (2007) Contemporary implant dentistry, Elsevier Health Sciences.

13. Zarb GA, Albrektsson T, Branemark PI (1985) Tissue-integrated prostheses: osseointegration in clinical dentistry, Quintessence.

14. Kumar G (2014) Orban's Oral Histology \& Embryology, Elsevier Health Sciences.

15. Schroeder A, van der Zypen E, Stich H, Sutter F (1981) The reactions of bone, connective tissue, and epithelium to endosteal implants with titanium-sprayed surfaces, Journal ofMaxillofacial Surgery 9: 15-25.

16. De Putter M, de Lange G, de Groot, K. (1985) Permucosla dental implants of dense hydroxyapatite: Fixation in alveolar bone, In Proc. Int. Congress on Tissue Integration in Oral and Maxillofacial Reconstruction, pp 389-394.

17. Davies JE (1998) Mechanisms of endosseous integration. Int J Prosthodont11: 391401.[Crossref]

18. Davies JE (2003) Understanding peri-implant endosseous healing. Journal of Dental Education 67: 932-949.

19. Kuzyk PR,Schemitsch EH (2011) The basic science of peri-implant bone healing. Indian Journal ofOrthopaedics 45: 108.

20. Kasemo B (2002) Biological surface science, Surface science 500: 656-677.

21. Schenk R, Hunziker E (1994) Histologic and ultrastructural features of fracture healing, Bone Formation and Repair. Rosemont, IL: American Academy of Orthopaedic Surgeons 117.

22. Brunski JB (1999) In vivo bone response to biomechanical loading at the bone/dentalimplant interface.AdvancesinDental Research 13: 99-119.

23. Hoshaw S, Watson J,Schaffler M, Fyhrie D (1995) Microdamage at bone-implant interfaces affects bone remodeling activity.Trans Orthop Res Soc 20: 188.

24. Roberts WE (1988) Bone tissue interface. Journal ofDental Education 52: 804-809.

25. Roberts TT, Rosenbaum AJ (2012) Bone grafts, bone substitutes and orthobiologics: The bridge between basic science and clinical advancements in fracture healing, Organogenesis 8: 114-124.

26. Frost HM (2009) Wolff's Law and bone's structural adaptations to mechanical usage: an overview for clinicians.

27. Bowers KT, Keller JC, Randolph BA, Wick DG, Michaels CM (1991) Optimization of surface micromorphology for enhanced osteoblast responses in vitro.The International Journal of Oral \& Maxillofacial Implants 7: 302-310. 
28. Sul YT, Johansson CB, Albrektsson T (2001) Oxidized titanium screws coated with calcium ions and their performance in rabbit bone.The International Journal of Oral \& Maxillofacial Implants 17: 625-634.

29. Jimbo R, Ono D, Hirakawa Y, Odatsu T, Tanaka T,et al. (2011) Accelerated PhotoInduced Hydrophilicity Promotes Osseointegration: An Animal Study.Clinical Implant Dentistry andRelated Research 13: 79-85.

30. Lee JK, Cho LR, Um HS, Chang BS, Cho KS (2012) Bone formation and remodeling of three different dental implant surfaces with Escherichia coli-derived recombinant human bone morphogenetic protein 2 in a rabbit model.The International Journal of Oral \& Maxillofacial Implants 28: 424-430.

31. Alghamdi H, Cuijpers V, Wolke J, Van den Beucken J, Jansen J (2013) Calciumphosphate-coated oral implants promote osseointegration in osteoporosis.Journal of Dental Research.

32. Wennerberg A, Albrektsson T, Lausmaa J (1996) Torque and histomorphometric evaluation of cp titanium screws blasted with 25 -and 75 - $\mu \mathrm{m}$-sized particles of A12O3, Journal of Biomedical Materials Research 30: 251-260.

33. Klokkevold PR, Nishimura RD, Adachi M, Caputo A (1997) Osseointegration enhanced by chemical etching of the titanium surface. A torque removal study in the rabbit, Clinical Oral Implants Research 8: 442-447.

34. Mustafa K, Wroblewski J, Hultenby K, Silva Lopez B, Arvidson K (2000) Effects of titanium surfaces blasted with $\mathrm{TiO} 2$ particles on the initial attachment of cells derived from human mandibular bone.Clinical Oral Implants Research 11: 116-128.

35. Li H, Yan F, Lei L, Li Y, Xiao Y (2009) Application of autologous cryopreserved bone marrow mesenchymal stem cells for periodontal regeneration in dogs.Cells Tissues Organs 190: 94-101.

36. Marei MK, Saad MM, El-Ashwah AM, El-Bckly RM, Al-Khodary MA (2009) Experimental formation of periodontal structure around titanium implants utilizing bone marrow mesenchymal stem cells: A pilot study. Journal of Oral Implantology 35: 106-129.

37. Choi BH(1999) Periodontal ligament formation around titanium implants using cultured periodontal ligament cells: a pilot study.The International Journal of Oral \& Maxillofacial Implants 15: 193-196.

38. Kirschstein RL, Skirboll LR (2001) Stem cells: scientific progress and future research directions, National Institutes of Health, Department of Health and Human Services.

39. Lin Y, Gallucci G, Buser D, Bosshardt,D,Belser U, et al. (2011) Bioengineered periodontal tissue formed on titanium dental implants.Journal of Dental Research 90: 251-256.

40. Gronthos S, Mankani M, Brahim J, Robey PG, Shi S (2000) Postnatal human dental pulp stem cells (DPSCs) in vitro and in vivo, Proceedings of the National Academy of Sciences 97: 13625-13630.

41. Miura M, Gronthos S, Zhao M, Lu B, Fisher LW, et al. (2003) SHED: stem cells from human exfoliated deciduous teeth, Proceedings of the National Academy of Sciences 100: 5807-5812.

42. Seo BM, Miura M, Gronthos S, Bartold PM, Batouli S, et al. (2004) Investigation of multipotent postnatal stem cells from human periodontal ligament. The Lancet 364: 149-155.

43. Sonoyama W, Liu Y, Yamaza T, Tuan RS, Wang S, et al. (2008) Characterization of the apical papilla and its residing stem cells from human immature permanent teeth: a pilot study.Journal of Endodontics 34: 166-171

44. Morsczeck C, Götz W, Schierholz J, Zeilhofer F, Kühn U, et al. (2005) Isolation of precursor cells (PCs) from human dental follicle of wisdom teeth, Matrix Biology 24: 155-165.

45. Huang GJ, Gronthos S, Shi S (2009) Mesenchymal stem cells derived from dental tissues vs. those from other sources: their biology and role in regenerative medicine. Journal of Dental Research 88: 792-806.

46. Yokoi T, Saito M, Kiyono T, Iseki S, Kosaka K, et al. (2007) Establishment of immortalized dental follicle cells for generating periodontal ligament in vivo, Cell and Tissue Research 327: 301-311.

47. Arceo N, Sauk JJ, Moehring J, Foster RA, Somerman MJ (1991) Human periodontal cells initiate mineral-like nodules in vitro.Journal of Periodontology 62: 499-503.

48. Sonoyama W, Liu Y, Fang D, Yamaza T, Seo BM, et al. (2006) Mesenchymal stem cellmediated functional tooth regeneration in swine.Plos One 1, e79.

49. Nyman S, Gottlow J, Karring T, Lindhe J (1982) The regenerative potential of the periodontal ligament.Journal of Clinical Periodontology 9: 257-265.
50. Takata T, Katauchi K, Miyauchi M, Ogawa I, Akagawa Y, et al. (1995) Periodontal tissue regeneration on the surface of synthetic hydroxyapatite implanted into root surface.Journal of Periodontology 66: 125-130.

51. Dogan, A, Özdemir A, Kubar A,Oygür T (2002) Assessment of periodontal healing by seeding of fibroblast-like cells derived from regenerated periodontal ligament in artificial furcation defects in a dog: a pilot study.Tissue Engineering 8: 273-282.

52. Aukhil I, Pettersson E, Suggs C (1986) Guided Tissue Regeneration: An Experimental Procedure in Beagle Dogs.Journal of Periodontology 57: 727-734.

53. Nyman S, Lindhe J, Karring T, Rylander H (1982) New attachment following surgical treatment of human periodontal disease.Journal of Clinical Periodontology 9: 290-296.

54. Gottlow J, Nyman S, Lindhe J, Karring T, WennströmJ (1986) New attachment formation in the human periodontium by guided tissue regeneration Case reports. Journal of Clinical Periodontology 13: 604-616.

55. Warrer K, Karring T, Gotfredsen K (1993) Periodontal ligament formation around different types of dental titanium implants. I The self-tapping screw type implant system. Journal of Periodontology 64: 29-34.

56. Guarnieri R, Giardino L, Crespi R, Romagnoli R (2001) Cementum formation around a titanium implant: a case report. The International Journal of Oral \& Maxillofacial Implants 17: 729-732.

57. Buser D, Warrer K, Karring T, Stich H (1989) Titanium implants with a true periodontal ligament: an alternative to osseointegrated implants, The International Journal of Oral \& Maxillofacial Implants 5: 113-116.

58. Jahangiri L, Hessamfar R, Ricci JL (2005) Partial generation of periodontal ligament on endosseous dental implants in dogs. Clinical Oral Implants Research 16: 396-401.

59. Urabe M, Hosokawa R, Chiba D, Sato Y,Akagawa Y (2000) Morphogenetic behavior of periodontium on inorganic implant materials: An experimental study of canines. Journal of Biomedical Materials Research 49: 17-24.

60. Rinaldi JC, Arana-Chavez VE (2010) Ultrastructure of the interface between periodontal tissues and titanium mini-implants, Angle Orthodontist 80: 459-465.

61. Gault P, Black A, Romette JL, Schroeder K, Thillou F, et al. (2010) Tissue-engineered ligament: implant constructs for tooth replacement, Journal of Clinical Periodontology 37: 750-758.

62. Piattelli A, Cordioli GP, Passi P, Trisi P (1994) Formation of dental hard tissues and periodontal ligament around titanium implants after tooth-bud injury: A pilot study, International Journal ofOral andMaxillofacial Implants 9: 417-417.

63. Wei F, Song T, Ding G, Xu J, Liu Y, et al. (2013) Functional tooth restoration by allogeneic mesenchymal stem cell-based bio-root regeneration in swine, Stem cells and development 22: 1752-1762.

64. Takata T, Katauchi K, Akagawa Y, Nikai H (1993) New connective tissue attachmen formation on various biomaterials implanted in roots. The International Journal of Oral \& Maxillofacial Implants 9: 77-84.

65. Caiazza S, Taruscio D, Ciaralli F, Crateri P, Chistolini P, et al. (1991) Evaluation of an experimental periodontal ligament for dental implants.Biomaterials 12: 474-478.

66. Kano T, Yamamoto R, Miyashita A, Komatsu K, Hayakawa T, et al. (2012) Regeneration of periodontal ligament for apatite-coated tooth-shaped titanium implants with and without occlusion using rat molar model.Journal ofHard Tissue Biology 21: 189-202.

67. Parlar A, Bosshardt DD, Ünsal B, Çetiner D, Haytaç C, et al. (2005) New formation of periodontal tissues around titanium implants in a novel dentin chamber model.Clinical Oral Implants Research 16: 259-267.

68. Miyashita A, Komatsu K, Shimada A, Kokubo Y, Shimoda S, et al. (2005) Effect of remaining periodontal ligament on the healing-up of the implant placement.Journal ofHard Tissue Biology 14: 198-200.

69. Kawaguchi H, Hirachi A, Hasegawa N, Iwata T,Hamaguchi H, et al. (2004) Enhancement of periodontal tissue regeneration by transplantation of bone marrow mesenchymal stem cells.Journal of Periodontology 75: 1281-1287.

70. Lang H, Schüler N, Nolden R (1998) Attachment formation following replantation of cultured cells into periodontal defects-a study in minipigs.Journal of Dental Research 77: 393-405.

71. Aukhil I, Simpson D, Suggs C, Pettersson E (1986) In vivo differentiation of progenitor cells of the periodontal ligament.Journal of Clinical Periodontology 13: 862-868.

72. Buser D, Warrer K, Karring T (1990) Formation of a periodontal ligament around titanium implants.Journal of Periodontology 61: 597-601.

73. Avery JK, Steele PF (2006) Essentials of oral histology and embryology: a clinical approach, Mosby. 
74. Stillman BC (2002) Making sense of proprioception: the meaning of proprioception, kinaesthesia and related terms.Physiotherapy 88: 667-676.

75. Rhodin J (1974) Rhodin's Histology, Oxford University Press.

76. Lewinsky W, Stewart D (1937) A Comparative Study of the Innervation of the Periodontal Membrane:(Section of Odontology), Proceedings of the Royal Society of Medicine 30: 1355.

77. Lewinsky W, Stewart D (1937) The innervation of the periodontal membrane of the cat, with some observations on the function of the end-organs found in that structure. Journal of Anatomy 71: 232.

78. Bernick S (1966) Vascular and nerve supply to the molar teeth of guinea pigs.Journal of Dental Research 45: 249-260.

79. Allgood J (1973) Neuromuscular control of mandibular movement.Dental Student 52: 24-25.

80. Falin L (1958) The morphology of receptors of the tooth.Cells Tissues Organs 35: 257-276.

81. Stewart D (1927) Some aspects of the innervation of the teeth. Proceedings of the Royal Society of Medicine 20: 1675.

82. Sakada S (1974) Mechanoreceptors in fascia, periosteum and periodontal ligament. The Bulletin of Tokyo Medical and Dental University 21: 11 .

83. Pfaffmann C (1939) Afferent impulses from the teeth resulting from a vibratory stimulus. The Journal of Physiology 97: 220-232.

84. Wagers PW, Smith CM (1960) Responses in dental nerves of dogs to tooth stimulation and the effects of systemically administered procaine, lidocaine and morphine.Journal of Pharmacology andExperimental Therapeutics 130: 89-105.

85. Pfaffmann C (1939) Afferent impulses from the teeth due to pressure and noxious stimulation.The Journal of Physiology 97: 207-219.

86. Maeda T, Ochi K, Nakakura-Ohshima K, Youn S,Wakisaka S (1999) The Ruffin ending as the primary mechanoreceptor in the periodontal ligament: its morphology, cytochemical features, regeneration, and development.Critical Reviews In Oral Biology \&Medicine 10: 307-327.

87. Freeman M,Wyke B (1967) The innervation of the knee joint. An anatomical and histological study in the cat.Journal of Anatomy 101: 505.

88. Kurpad A, Vaz M, Raj TD (2013) Guyton \& Hall: Textbook of Medical Physiology A South Asian Edition, Elsevier India.

89. Michelson JD, Hutchins C (1995) Mechanoreceptors in human ankle ligaments.Journal ofBone \&Joint Surgery. British Volume 77: 219-224.

90. Lang NP, Lindhe J (2015) Clinical periodontology and implant dentistry. John Wiley \& Sons.

91. Anderson DJ, Hannam A, Matthews B (1970) Sensory mechanisms in mammalian teeth and their supporting structures.Physio. Rev 50: 171-195.

92. Linden R, Scott B (1989) Distribution of mesencephalic nucleus and trigeminal ganglion mechanoreceptors in the periodontal ligament of the cat.The Journal of Physiology 410: 35-44.

93. Cash R, Linden R (1982) The distribution of mechanoreceptors in the periodontal ligament of the mandibular canine tooth of the cat.The Journal of Physiology 330: 439-447.

94. Chauncey H, Glass R, Alman J (1989) Dental caries.Caries Research 23: 200-205.

95. Abarca M, Steenberghe D, Malevez C, Jacobs R (2006) The neurophysiology of osseointegrated oral implants. A clinically underestimated aspect.Journal of Oral Rehabilitation 33: 161-169.

96. Misch CE (2014) Dental implant prosthetics, Elsevier Health Sciences.

97. Batista M, Bonachela W, Soares J (2008) Progressive recovery of osseoperception as a function of the combination of implant-supported prostheses.Clinical Oral Implants Research 19: 565-569.

98. Enkling N, Heussner S, Nicolay C, Bayer S, MericskeStern R, et al. (2012) Tactile Sensibility of Single-Tooth Implants and Natural Teeth Under Local Anesthesia of the Natural Antagonistic Teeth, Clinical Implant Dentistry and Related Research 14: 273-280.

99. Jacobs R, van Steenberghe D (2006) From osseoperception to implant-mediated sensory-motor interactions and related clinical implications.Journal ofOral Rehabilitation 33: 282-292.

100. Klineberg I, Murray G (1999) Osseoperception: sensory function and proprioception. Advances In Dental Research 13: 120-129.
101. Lobbezoo F, Trulsson M, Jacobs R, SvenssonP, Cadden SW, et al. (2001) Topical review: modulation of trigeminal sensory input in humans: mechanisms and clinical implications.Journal of Orofacial Pain 16: 9-21.

102. Trulsson M (2005) Sensory and motor function of teeth and dental implants: a basis for osseoperception.Clinical and Experimental Pharmacology and Physiology 32: 119-122.

103. Van Steenberghe D, Jacobs R (2006) Jaw motor inputs originating from osseointegrated oral implants.Journal of Oral Rehabilitation 33: 274-281.

104. HabreHallage P, Dricot L, Jacobs R, Van Steenberghe D, Reychler H, et al. (2012) Brain plasticity and cortical correlates of osseoperception revealed by punctate mechanical stimulation of osseointegrated oral implants during fMRI.Eur J Oral Implantol 5: 175-190.

105. BouSerhal C, Jacobs R, van Steenberghe D (1998) Stereognostic ability of teeth and implants: a comparison between various prosthetic superstructures, status: published.

106. KlinebergI, Calford M,Dreher B, Henry P,Macefield V, et al. (2005) A consensus statement on osseoperception.Clinical andExperimental Pharmacology andPhysiology 32: 145-146.

107. Yan C, Ye L, Zhen J, Ke L, Gang L (2008) Neuroplasticity of edentulous patients with implant-supported full dentures.European Journal of Oral Sciences 116: 387-393.

108. Mühlbradt L, Ulrich R, Möhlmann H, Schmid H (1988) Mechanoperception of natural teeth versus endosseous implants revealed by magnitude estimation.The International Journal of Oral \& Maxillofacial Implants 4: 125-130.

109. Jacobs R, van Steenberghe D (1992) Comparison between implant-supported prostheses and teeth regarding passive threshold level. The International Journal of Oral \& Maxillofacial Implants 8: 549-554.

110. Jacobs R, Van Steenberghe D (1991) Comparative evaluation of the oral tactile function bv means of teeth or implant-supported prostheses.Clinical Oral Implants Research 2: 75-80

111. Hämmerle C, Wagner D, Brägger U,Lussi A, Karayiannis A, et al. (1995) Threshold of tactile sensitivity perceived with dental endosseous implants and natural teeth. Clinical Oral Implants Research 6: 83-90.

112. Bonte B, Linden R, Scott B, van Steenberghe D (1993) Role of periodontal mechanoreceptors in evoking reflexes in the jaw-closing muscles of the cat The Journal of Physiology 465: 581-594.

113. Weiner S, Sirois D, Ehrenberg D, Lehrmann N, Simon B, et al. (2003) Sensory responses from loading of implants: a pilot study.The International Journal of Oral \& Maxillofacial Implants 19: 44-51.

114. Rowe M, Tracey D, Mahns D, Sahai V,Ivanusic J (2005) Mechanosensory perception: are there contributions from bone-associated receptors.Clinical and Experimental Pharmacology and Physiology 32: 100-108.

115. Thilander B (1961) Innervation of the temporo-mandibular joint capsule in man Trans. R. Sch. Dent. Stockh. Umea 7: 9.

116. Dubner R (2013) The neural basis of oral and facial function.Springer Science \& Business Media.

117. Klineberg I, Greenfield B, Wyke B (1971) Afferent discharges from temporomandibular articular mechanoreceptors: an experimental analysis of their behavioural characteristics in the cat.Archives of Oral Biology 16: 1463-1479.

118. Proske U, Schaible HG, Schmidt R (1988) Joint receptors and kinaesthesia, Experimental Brain Research 72: 219-224.

119. Clark FJ, Horch KW (1986) Kinesthesia, Handbook of perception and human performance 1: 13-11.

120. Lund J, Matthews B (1981) Responses of temporomandibular joint afferents recorded in the Gasserian ganglion of the rabbit to passive movements of the mandible, Oralfacial sensory and motor functions. Quintessence Tokyo pp: 153-160.

121. Matthews PB (1988) Proprioceptors and their contribution to somatosensory mapping; complex messages require complex processing.Canadian Journal of Physiology and Pharmacology 66: 430-438.

122. Johansson RS, Trulsson M, Olsson K, Westberg KG (1988) Mechanoreceptor activity from the human face and oral mucosa.Experimental Brain Research 72: 204-208.

123. Johansson RS, Trulsson M, Olsson K, Abbs JH (1988) Mechanoreceptive afferent activity in the infraorbital nerve in man during speech and chewing movements, Experimental Brain Research 72: 209-214.

124. McClean MD, Dostrovsky JO,Lee L, Tasker RR (1990) Somatosensory neurons in human thalamuc respond to speech-induced orofacial movements.Brain Research 513: 343-347. 
125. DarianSmith I (1984) The sense of touch: performance and peripheral neural processes.Comprehensive Physiology.

126. Mason RM (1967) Studies of oral perception involving subjects with alterations in anatomy and physiology, In Second symposium on oral sensation and perception. Charles C Thomas Publisher.Springfield pp: 295-301.

127. Walker HK (1990) 61 Cranial Nerve V: The Trigeminal Nerve, Clinical Methods: The History, Physical, andLaboratory Examinations, 318.

128. Penfield W, Rasmussen T (1950) The cerebral cortex of man; a clinical study of localization of function.

129. Eickhoff SB, Amunts K, Mohlberg H, Zilles K (2006) The human parietal operculum. II. Stereotaxic maps and correlation with functional imaging results.Cerebral Cortex 16: $268-279$.

130. Penfield W, Boldrey E (1937) Somatic motor and sensory representation in the cerebral cortex of man as studied by electrical stimulation.Brain 60: 389-443.

131. Miyamoto JJ, Honda M, Saito DN, Okada T, Ono T, et al. (2006) The representation of the human oral area in the somatosensory cortex: a functional MRI study.Cerebral Cortex 16: 669-675.

132. Brodmann K (1909) Comparative localization theory of the cerebral cortex in its principles represented on the basis of the cell structure. Barth.

133. Brodmann K (2007) Brodmann's: Localisation in the Cerebral Cortex, Springer Science \& Business Media.

134. Chen TL, Babiloni C, Ferretti A, Perrucci MG, Romani GL,et al. (2008) Human secondary somatosensory cortex is involved in the processing of somatosensory rare stimuli: an fMRI study.Neuroimage 40: 1765-1771.

135. Huang RS, Sereno MI (2007) Dodecapus: an MR-compatible system for somatosensory stimulation.Neuroimage 34: 1060-1073.

136. DarianSmith I (1966) Neural mechanisms of facial sensation.Int Rev Neurobiol 9: 301-395.

137. Dubner R, Sessle BJ, Storey AT (1978) Tooth pulp and dentine. In The neural basis of oral and facial function. pp 109-146.

138. Huang C, Hiraba H, Sessle B (1989) Input-output relationships of the primary face motor cortex in the monkey.Journal of Neurophysiology 61: 350-362.

139. Rossignol S, Lund J, Drew T (1988) The role of sensory inputs in regulating patterns of rhythmical movements in higher vertebrates.Neural Control of Rhythmic Movements In Vertebrate's pp: 201-283.

140. Murray G, Sessle B (1992) Functional properties of single neurons in the face primary motor cortex of the primate. I. Input and output features of tongue motor cortex.Journal of Neurophysiology 67: 747-758.

141. Klineberg, I. (1980) Influences of temporomandibular articular mechanoreceptors on functional jaw movements.Journal of Oral Rehabilitation 7: 307-317.

142. Jacobs R, Steenberghe DV (1994) Role of periodontal ligament receptors in the tactile function of teeth: a review.Journal of Periodontal Research 29: 153-167.

143. Rowe M, Turman A, Murray G, Zhang H (1996) Parallel organization of somatosensory cortical areas I and II for tactile processing.Clinical and Experimental Pharmacology and Physiology 23: 931-938.

144. Ghosh S, Murray G, Turman A, Rowe M (1994) Corticothalamic influences on transmission of tactile information in the ventroposterolateral thalamus of the cat: effect of reversible inactivation of somatosensory cortical areas I and II, Experimental Brain Research 100: 276-286.

145. Chapman CE (1994) Active versus passive touch: factors influencing the transmission of somatosensory signals to primary somatosensory cortex.Canadian Journal of Physiology and Pharmacology 72: 558-570.

146. Kaas JH (1991) Plasticity of sensory and motor maps in adult mammals.Annual Review of Neuroscience 14: 137-167.

147. Merzenich MM, Wang X, Xerri C, Nudo R (1996) Functional plasticity of cortical representations of the hand, In Somesthesis and the Neurobiology of the Somatosensory Cortex, pp 249-269.
148. Van Loven K, Jacobs R, Van Hees J, Van Huffel S, Van Steenberghe D (2001) Trigeminal somatosensory evoked potentials in humans.Electromyography and Clinical Neurophysiology 41: 357-375.

149. Chatrian GE, de Lima VMF, Lettich E, Canfield RC, Miller RC, et al. (1982) Electrical stimulation of tooth pulp in humans. II. Qualities of sensations.Pain 14: 233-246.

150. Raab W, Ott R (1991) Studies on the perception of periodontal stimuli.German Dental Magazine 46: 349-351.

151. Bennett M, Jannetta P (1980) Trigeminal evoked potentials in humans, Electroencephalography and Clinical Neurophysiology 48: 517-526.

152. Barker G, Bennett A, Wastell D (1987) Applications of trigeminal somatosensory evoked potentials (TSEPs) in oral and maxillofacial surgery.British Journal ofOral andMaxillofacial Surgery 25: 308-313.

153. Duncan RC, Storey AT, Rugh JD, Parel SM (1992) Electromyographic activity of the jaw-closing muscles in patients with osseointegrated implant fixed partial dentures. The Journal of Prosthetic Dentistry 67: 544-549.

154. Stuge U, Brodin P, Bjørnland T (1992) Masseter muscle reflex evoked by tapping on osseointegratedFrialit implants. The International Journal of Oral \& Maxillofacial Implants 8: 650-654.

155. Jacobs R, van Steenberghe D (1994) Qualitative evaluation of the masseteric poststimulus EMG complex following mechanical or acoustic stimulation of osseointegrated oral implants.The International Journal of Oral \& Maxillofacial Implants 10: 175-182.

156. Bonte B, Steenberghe D (1991) Masseteric post-stimulus EMG complex following mechanical stimulation of osseointegrated oral implants.Journal of Oral Rehabilitation 18: 221-229.

157. Nakahara H, Nakasato N, Kanno A, Murayama S, Hatanaka K, et al. (2004) Somatosensory-evoked fields for gingiva, lip, and tongue.Journal of Dental Research 83: 307-311.

158. Kubo K, Shibukawa Y, Shintani M, Suzuki T, Ichinohe T, et al. (2008) Cortical representation area of human dental pulp.Journal of Dental Research 87: 358-362.

159. Bessho H, Shibukawa Y, Shintani M, Yajima Y, Suzuki T, et al. (2007) Localization of palatal area in human somatosensory cortex.Journal of Dental Research 86: 265-270.

160. Shimazaki T, Otsuka T, Akimoto S, Kubo K, Sato S, et al. (2012) Comparison of brain activation via tooth stimulation Journal of Dental Research.

161. Ettlin D, Zhang H, Lutz K, Järmann T, Meier D (2004) Cortical activation resulting from painless vibrotactile dental stimulation measured by functional magnetic resonance imaging (FMRI).Journal of Dental Research 83: 757-761.

162. Jantsch H, Kemppainen P, Ringler R, Handwerker H, Forster C (2005) Cortica representation of experimental tooth pain in humans.Pain 118: 390-399.

163. Guest S, Grabenhorst F, Essick G, Chen Y, Young M, et al. (2007) Human cortical representation of oral temperature.Physiology \& Behavior 92: 975-984.

164. Van Steenberghe D (1979) The role and function of periodontal neural receptors in man.Acco.

165. Miles TS, Nauntofte B, Svensson P (2004) Clinical oral physiology. Quintessence Copenhagen.

166. Lundqvist S,Haraldson $\mathrm{T}$ (1984) Occlusal perception of thickness in patients with bridges on osseointegrated oral implants.European Journal ofOral Sciences 92: 88-92.

167. Keller D, Hämmerle C, Lang N (1996) Thresholds for tactile sensitivity perceived with dental implants remain unchanged during healing phase of 3 months.Clinical Oral Implants Research 7: 48-54.

168. El-Sheikh AM, Hobkirk JA, Howell P, Gilthorpe MS (2002) Changes in passive tactile sensibility associated with dental implants following their placement.The International Journal of Oral \& Maxillofacial Implants 18: 266-272.

169. Jacobs R, Serhal CB, van Steenberghe D (1998) Oral stereognosis: a review of the literature.Clinical Oral Investigations 2: 3-10.

170. Litvak H, Silverman SI, Garfinkel L (1971) Oral stereognosis in dentulous and edentulous subjects.The Journal of Prosthetic Dentistry 25: 139-151.

Copyright: (2017 Das S. This is an open-access article distributed under the terms of the Creative Commons Attribution License, which permits unrestricted use, distribution, and reproduction in any medium, provided the original author and source are credited. 